\title{
Maciej Karczewski
}

Białystok

\section{Dzieje zasiedlania Kotliny Biebrzańskiej w epoce żelaza}

Szkic ten jest kontynuacją prezentacji problematyki archeologii epoki żelaza na obszarze Kotliny Biebrzańskiej, rozpoczętej w czwartym tomie „Białostockich Tek Historycznych"1. Dotychczas omówione zostały dzieje badań archeologicznych tego terenu. Zgromadzona w ich wyniku baza źródłowa, nader fragmentaryczna i wyrywkowa, stwarza podstawę do postawienia wielu pytań, lecz rzadko wystarcza do udzielenia na nie odpowiedzi.

\section{Stan źródeł archeologicznych do badań nad epoką żelaza obszarów nadbiebrzańskich}

Bibliografia archeologiczna Jaćwieży Aleksandra Kamińskiego ukazała rzeczywisty stan rozpoznania archeologicznego Kotliny Biebrzańskiej i sąsiadujących z nią obszarów do lat pięćdziesiątych XX wieku. Mimo trwających przez przeszło 150 lat poszukiwań i badań, zgromadzona została jedynie garść informacji o zaledwie dwudziestu stanowiskach archeologicznych ${ }^{2}$. Bibliografia obejmuje, co prawda czasy od I do XIII wieku n.e., nie uwzględnia więc całej wczesnej epoki żelaza oraz późnego średniowiecza i czasów nowożytnych, ale dla tych okresów chronologicznych sytuacja wygląda jeszcze gorzej. Poza badaniami wykopaliskowymi przeprowadzonymi przez Brunona Erlicha ${ }^{3}$ na grodzisku w Rajgrodzie brak jest jakichkolwiek informacji o odkryciach stanowisk archeologicznych z wczesnej epoki żelaza. Gdyby nie to grodzisko, do lat pięć-

1 M. Karczewski, Historia badań archeologicznych nad epokq żelaza Kotliny Biebrzańskiej, „Białostockie Teki Historyczne”, t. 4/2006, s. 11-39.

2 A. Kamiński, Materiały do bibliografii archeologicznej Jaćwieży od I do XIII w., „Materiały Starożytne”, t. I, 1956, s. 216, 217, 220, 221, 232, 235, 237, 244-245, 247, 261.

3 B. Erlich, Der Schlossberg in Rajgród (Polen), [w:] Festschrift Adalbert Bezzenberger um 14 April 1921 dargebracht von seiner Freuden und Schülern, Göttingen 1921, s. 31-38, tabl. IV. 
dziesiątych $\mathrm{XX}$ wieku, trudno byłoby również mówić o badaniach z zakresu archeologii historycznej ${ }^{4}$.

Najłatwiejszą do zidentyfikowania w terenie kategorią stanowisk archeologicznych są grodziska. Można więc przyjąć, że dla obszarów nadbiebrzańskich dysponujemy ich pełną listą. Na północ i zachód od Biebrzy są to grodziska w Rajgrodzie, Pieńkach - Grodzisku, Samborach i Wiźnie, na południe od niej - grodziska we wsiach Grodzisk i Grodziszczany (ryc. 1) $)^{5}$. Pięć z nich - w Grodziszczanach, Pieńkach-Grodzisku, Rajgrodzie, Samborach i Wiźnie w okresie po II wojnie światowej, objęte zostały systematycznymi badaniami wykopaliskowymi. Natomiast grodzisko pod wsią Grodzisk znane jest jedynie z opisów i poszukiwań powierzchniowych prowadzonych przez Romana Jakimowicza i Aleksandra Kamińskiego ${ }^{6}$.

Wyniki wieloletnich badań wykopaliskowych przeprowadzonych w latach 1967-1971 na grodzisku w Wiźnie nie doczekały się dotychczas pełnego opracowania. Efekty prac badawczych z lat 1968-1970 zostały, co prawda przedstawione w pracy magisterskiej Ireny Jastrzębskiej: „Grodzisko w Wiźnie, pow. Łomża w świetle badań prowadzonych w latach 1968-1970”, obronionej w Katedrze Archeologii Pradziejowej Uniwersytetu Warszawskiego w 1972 roku$^{7}$, ale nie wyczerpuje ona rozległej problematyki związanej z tym grodziskiem ${ }^{8}$. Natomiast badania z lat 1967 i 1971 są przedmiotem jedynie zwięzłych sprawozdań zamieszczanych w kolejnych tomach „Informatora Archeologicznego”. Poza wstępnym określeniem układu warstw i chronologii grodziska, w 1967 roku poczynione zostały również obserwacje stratygraficzne profili powstałych na skutek

\footnotetext{
${ }^{4}$ W 2007 r., już po złożeniu artykułu do druku, ukazało się podsumowanie stanu badań nad wczesnym średniowieczem północno-wschodniego Mazowsza autorstwa Elżbiety Kowalczyk-Heyman, obejmujące obszar międzyrzecza Narwi i Biebrzy. Zawarte w nim krytyczne uwagi dotyczące m.in. uwarunkowań rozwoju badań archeologicznych nad wczesnym średniowieczem tych terenów w czasach po II wojnie światowej, stanu publikacji wyników prac wykopaliskowych, czy też roli rzeki Brzozówki w kształtowaniu wczesnośredniowiecznej sieci osadniczej należy uznać za dyskusyjne (por. E. Kowalczyk-Heyman, Stan badan archeologicznych nad wczesnym średniowieczem pótnocno-wschodniego Mazowsza, „Światowit”, t. VI (XLVII), Fascykuł B, 2006, s. 73-79).

5 W zestawieniu pomięto grodzisko w Niewiarowie nad Nereślą, wiązane przez Aleksandra Kamińskiego z ziemią goniądzką (por. A. Kamiński, Pogranicze polsko-rusko-jaćwieskie między Biebrzq i Narwia, ,Rocznik Białostocki”, t. IV, 1963, s. 12-13, ryc. 1) jako położone poza obszarem wydzielonym na potrzeby tego opracowania.

6 J. Antoniewicz, Zabytki wczesnośredniowieczne, odkryte we wsi Pieńki - Grodzisko, pow. Łomża, „Sprawozdania P.M.A.”, t. VI, z. 1-2, s. 126; A. Kamiński, Wizna na tle pogranicza polsko-rusko-jaćwieskiego, „Rocznik Białostocki”, t. I, 1961, s. 11, przyp. 12.

7 Maszynopis w Archiwum Działu Archeologii Muzeum Podlaskiego.

8 D. Jaskanis, Grodzisko w Rajgrodzie w świetle źródeł archeologicznych. Wyniki konserwatorskich badań zabezpieczających z 1969 roku, „Biuletyn Konserwatorski Województwa Podlaskiego”, z. 7, s. 113-114.
} 
podcinania przez orkę dolnej części zewnętrznego stoku wału, rejestrując pionowe pale i poziome belki z jego konstrukcji ${ }^{9}$.

W chwili podjęcia badań, grodzisko w Wiźnie miało dobrze czytelne relikty umocnień, z których większość widoczna jest również dzisiaj. Jest to rozległe, owalne wyniesienie, powstałe w wyniku odcięcia od północy głęboką fosą części cypla położonego na skraju doliny Narwi ${ }^{10}$. Średnice grodziska wynoszą: 105 (ew. 110) x 70 m. Otaczała je fosa nawadniana przez Narew. Obecnie ślady fosy są słabo czytelne. Dawniej - u schyłku XIX wieku była ona „obszerna i głęboka". Zasypano ją ziemią wykopywaną z wału grodziska ${ }^{11}$. Strome stoki wału zostały częściowo zniszczone. Podstawa stoku południowego uległa rozoraniu, a jego górną część przecięły okopy i schrony z czasów I wojny światowej. Stok wschodni przekopali poszukiwacze skarbów. Największemu zniszczeniu uległy fosa i stok północny. W cały obszar tej części fosy wszedł w obręb cmentarza parafialnego i dotychczas jest miejscem grzebania zmarłych. Na północnym stoku wału w początkach XX wieku zbudowano rampę mającą służyć konduktom pogrzebowym, co wiązało się z planami rozszerzenia zasięgu cmentarza również na majdan grodziska. Plany te nie zostały zrealizowane na skutek zakazu wydanego przez władze carskie ${ }^{12}$. Obecnie, górne części wału górujące nad majdanem, zachowały się tylko od północy i południa. Dodatkowym elementem umocnień, związanym najprawdopodobniej z późnośredniowieczną lub nowożytną historią grodu, była wieżą, o której informacje przekazywali mieszkańcy Wizny jeszcze w latach pięćdziesiątych XX wieku. Sam majdan grodziska jest nierówny, co najprawdopodobniej wynika $\mathrm{z}$ jego przekształceń $\mathrm{w}$ kolejnych fazach funkcjonowania grodu i zamku. Intensywność zasiedlania tego miejsca potwierdza też miąższość nawarstwień kulturowych dochodząca tu do $5 \mathrm{~m}^{13}$.

Prace wykopaliskowe przeprowadzone w latach 1967-1970 objęły znaczną przestrzeń północnej i zachodniej części majdanu grodziska oraz północną część jego wału. W ich wyniku wydzielono trzy fazy funkcjonowania wczesnośredniowiecznego grodu, odpowiadające trzem okresom przebudowy jego wału. W fazie pierwszej, przypadającej na wiek XI, na piaszczysto-gliniastej skarpie nadnarwiańskiej wzniesiony został pierwszy wał grodu. Wiadomo, że posadowiono go na warstwie drewna wzmacniającej naturalne podłoże. Podstawowym materiałem budowlanym była glina, a całość umacniała bliżej nieokreślona konstrukcja

\footnotetext{
9 Wizna, [w:] Informator Archeologiczny. Badania 1967, s. 381.

10 R. Jakimowicz, Sprawozdanie z działalności Państwowego Konserwatora Zabytków Przedhistorycznych na Okręg Warszawski, „Wiadomości Archeologiczne”, t. VIII, 1923, s. 204-205; B. Guerquin, Zamki w Polsce, Warszawa 1974, s. 308; L. Kajzer, St. Kołodziejski, J. Salm, Leksykon zamków w Polsce, Warszawa 2001, s. 541.

11 R. Jakimowicz, Sprawozdanie z ..., s. 206; A. Kamiński, Wizna..., s. 32, 34, przyp. 85.

12 R. Jakimowicz, Sprawozdanie z ..., s. 205-206.

13 I. Jastrzębska, Grodzisko w Wiźnie...
} 
drewniana. Drewnem wymoszczono również stok zewnętrzny wału. Wzniesione wówczas umocnienia, związane najprawdopodobniej z gródkiem strażniczym, były raczej skromne. Szerokość wału u podstawy wynosiła zaledwie $4 \mathrm{~m}$, a jego wysokość w chwili rozpoczęcia badań oszacowano na około $230 \mathrm{~cm}^{14}$.

Faza druga odpowiadała już grodowi kasztelańskiemu i przypadała głównie na wiek XII. Jego wał został wzmocniony i podwyższony, przy czym jako materiał budowlany posłużył głównie piasek i glina przeniesione z majdanu. Stan zachowania reliktów wału znacznie utrudniał jednoznaczne określenie techniki jego konstrukcji, jednak autorka opracowania wyników badań wysunęła przypuszczenie, że wzniesiono go w technice rusztowej. Wiadomo też, że zewnętrzny stok wału licowany był kamieniami, co znacznie podnosiło jego obronność i zabezpieczało przed ogniem. Również w tej fazie wokół grodu przekopana została fosa ${ }^{15}$.

Trzecia, najmłodsza faza umocnień związana była z późnośredniowiecznym i nowożytnym zamkiem książęcym. Przebudowa wału, jaka miała wówczas miejsce, ograniczyła się do podwyższenia jego korony przez nasypanie warstwy piasku i gliny. Zwieńczenie wału stanowiła palisada, którą wzmiankowały jeszcze szesnastowieczne źródła pisane. U schyłku tego stulecia zamek uległ zniszczeniu ${ }^{16}$.

Wyniki wykopalisk na grodzisku w Wiźnie dobrze odzwierciedlają ówczesne cele i strategię prac badawczych, ukształtowane jeszcze w ramach badań nad tysiącleciem Państwa Polskiego. Dążono w nich przede wszystkim do rozpoznania charakteru urządzeń obronnych i poznania militarnej funkcji obiektu. Koncentrowano się przy tym na nawarstwieniach wczesnośredniowiecznych, znacznie mniejszą wagę przypisując późniejszym - średniowiecznych i nowożytnych fazom użytkowania grodzisk ${ }^{17}$. W przypadku grodziska w Wiźnie doprowadziło to do pozostawienia bez odpowiedzi wielu ważnych pytań: poczynając od charakteru umocnień zamku książęcego, przez wygląd zabudowy wewnętrznej po całą gamę zagadnień związanych z funkcjonowaniem grodu i zamku w realiach politycznych i kulturowych Mazowsza oraz pogranicza Mazowsza, pruskich terytoriów plemiennych, później zaś państwa zakonnego w Prusach, Litwy oraz Rusi. Prowadzone tu dotychczas prace badawcze nie uwzględniały też w szerszym zakresie informacji zawartych w przekazach pisanych ${ }^{18}$. Porównanie danych archeologicznych i historycznych ograniczało się do stwierdzenia zbieżności dat ostatecznego upadku zamku w Wiźnie. Na podstawie źródeł pisanych początek

\footnotetext{
14 Ibidem.

15 Ibidem.

16 Ibidem.

17 L. Kajzer, Wstęp do archeologii historycznej w Polsce, Lódź 1996, s. 123.

18 A. Kamiński, Jaćwież. Terytorium, ludność, stosunki gospodarcze i społeczne, Łódź 1955, s. $48-49$, przyp. 55 .
} 
tego procesu wyznaczono na schyłek XV wieku. Na ten sam okres wskazują również źródła archeologiczne, licznie reprezentujące XIV-XV wieczną kulturę materialną i znacznie słabiej następne stulecia ${ }^{19}$.

Poza pracami wykopaliskowymi na grodzisku, w drugiej połowie lat sześćdziesiątych i w latach siedemdziesiątych XX wieku prowadzone też były poszukiwania powierzchniowe w jego sąsiedztwie. Odkryto dzięki nim ślady grobli lub mostu wizneńskiego, wielokrotnie wzmiankowanego w piętnastowiecznych źródłach pisanych. Odnaleziono je w odległości około $1 \mathrm{~km}$ na północ od grodu. $Z$ dawnej przeprawy przez Narew zachowały się do dziś ślady grobli zbudowanej z piasku i słupów drewnianych o średnicy dochodzącej do $50 \mathrm{~cm}$. Również na północ od grodu, bezpośrednio za fosą znajdowało się rozległe podgrodzie. Jego ślady zostały niemal zupełnie zniszczone przez znajdujący się tu cmentarz parafialny ${ }^{20}$.

W sąsiedztwie Wizny, na wysokości ujścia Biebrzy do Narwi, zlokalizowane jest grodzisko w Samborach, zwane „Okopem”21. Zajmuje ono część wyniesienia położonego na zachodniej krawędzi Kotliny Biebrzańskiej. Południowy fragment wyniesienia został wyodrębniony poprzez usypanie wału. Wał ten, licowany od zewnątrz kamieniami i otaczający pierścieniem całe grodzisko, jest jedynym możliwym do zidentyfikowania elementem umocnieńn ${ }^{22}$. Wymiary grodziska wynoszą: wzdłuż osi północ południe - $45 \mathrm{~m}$, wzdłuż osi wschód zachód - $25 \mathrm{~m}$. Największa, zachowana wysokość wału dochodzi do $4 \mathrm{~m}$. Od zachodu naturalną obronność wyniesienia podnosiła bezimienna struga. Większą część majdanu zajmuje owalny nasyp - kopica o wymiarach 20 x 10 m będąca prawdopodobnie pozostałością podstawy wieży. Ustalenie czasu funkcjonowania grodu w Samborach możliwe jest na podstawie fragmentów ceramiki zebranych z majdanu i wału grodziska w latach pięćdziesiątych XX wieku przez Aleksandra Kamińskiego oraz fragmentów naczyń ceramicznych odkrytych podczas badań wykopaliskowych przeprowadzonych w 1984 r. Nieliczne ułamki naczyń, jakie

\footnotetext{
19 I. Jastrzębska, Grodzisko w Wiżnie...

20 A. Kamiński, Wizna..., s. 35-36.

21 W dokumentacji konserwatorskiej grodzisko w Samborach określane jest jako stanowisko 1 w Rusi.
}

22 A. Kamiński podaje, że od północnego - zachodu, w odległości ok. $8 \mathrm{~m}$ od wału grodziska znajduje się wyniosłość, która może być pozostałością drugiego wału osłaniającego gród od północy (A. i J. Kamińscy, Grodzisko w miejscowości Sambory, pow. Łomża, „Wiadomości Archeologiczne", t. XXIII, z. 4, 1956, s. 363; A. Kamiński, Wizna..., s. 38. Przeprowadzone w 1984 r. przez Lecha Kaczmarka badania wykopaliskowe nie przyniosły rozstrzygnięcia tej kwestii. W niewielkim wykopie badawczym, założonym prostopadle do wału grodziska odkryte zostały natomiast pozostałości fosy. Jej lokalizacja zdaniem kierownika badań i autora sprawozdania sugerowała, „że we wczesnym średniowieczu grodzisko było mniejsze, niż obecnie." (por. L. Kaczmarek, Ruś, gm. Wizna, woj. Łomżyńskie, stanowisko 1 „Okop”, [w:] Informator Archeologiczny. Badania 1984, Warszawa 1985, s. 142-143). 
udało się Aleksandrowi Kamińskiemu odnaleźć pochodziły z garnków wczesnośredniowiecznych, przy czym dwa $\mathrm{z}$ nich na podstawie ornamentu dookolnych żłobków zostały datowane na XI-XIII wiek, co stało się podstawą do ustalenia chronologii grodziska ${ }^{23}$. Ustalenie innych ram czasowych przyniosły badania wykopaliskowe. Odkryta wówczas ceramika stałą się podstawą stwierdzenia, że „obiekt funkcjonował prawdopodobnie od XII do XIV wieku”24. Śladem późniejszego epizodu w dziejach grodziska była czaszka ludzka odnaleziona na dnie nowożytnego wkopu ${ }^{25}$.

W czasie badań powierzchniowych prowadzonych pod wsią Sambory, Aleksander Kamiński odnalazł też stanowisko archeologiczne, położone na tym samym wyniesieniu, bezpośrednio na północ od grodziska, które uznał za pozostałość osady podgrodowej. Z jego powierzchni zebrał dwa fragmenty ceramiki wczesnośredniowiecznej ${ }^{26}$.

Grodzisko w Pieńkach-Grodzisku, zwane „Okopem”, należy do typu nizinnego, z pierścieniowatym wałem ${ }^{27}$. Średnice grodziska wynoszą odpowiednio: północ - południe: $73 \mathrm{~m}$ i wschód - zachód: $68 \mathrm{~m}$, najwyższy wał posiada ono od strony południowej i wschodniej. Od strony zachodniej wał uległ zniszczeniu. W centralnej części majdanu znajduje się wywyższenie o wymiarach 30 x $30 \mathrm{~m}$, będące najprawdopodobniej pozostałością stołpu - podstawy wieży. Wał wzniesiony z piasku i gliny, licowany były od strony zewnętrznej lub na obu powierzchniach kamieniami ${ }^{28}$. Przeprowadzone w 1979 r., kierowane przez Włodzimierza Pelę badania wykopaliskowe wykazały istnienie na majdanie grodziska warstwy kulturowej ze skupiskami kamieni. Skupiska te miały być pozostałościami palenisk i świadczyć o tym, że majdan zabudowany był budynkami naziemnymi. Na skraju majdanu odkryte zostały relikty półziemianki. Ruchomy materiał zabytkowy, na który składały się fragmenty ceramiki naczyniowej, ,„przęśliki gliniane, noże i grot żelazny", stał się podstawą do datowania grodziska i przylegającej doń osady na XIII w. ${ }^{29}$

23 A. i J. Kamińscy, Grodzisko..., s. 363-364; A. Kamiński, Wizna..., s. 36-38, 40. Nie można przyjąć bez zastrzeżeń hipotezy o powstaniu grodu w Samborach w miejscu wcześniejszej osady wczesnośredniowiecznej, sprzed XI w. Została ona sformułowana wyłącznie w oparciu o kilka niezdobionych fragmentów ceramiki (A. i J. Kamińscy, Grodzisko..., s. 364.

24 L. Kaczmarek, Ruś..., s. 143.

25 Ibidem.

26 A. i J. Kamińscy, Grodzisko..., s. 363; A. Kamiński, Wizna.., s. 38.

27 A. Kamiński, Jaćwież..., s. 49-50, przyp. 56; tenże., Materiały..., s. 221, 240.

28 J. Antoniewicz, Zabytki wczesnośredniowieczne, odkryte we wsi Pieńki - Grodzisko, pow. Łomża, „Sprawozdania P.M.A.”, t. VI, z. 1-2, 1951, s. 127-128; A. Kamiński, Wizna..., s. 40-41; W. Pela, Pieńki-Grodzisko, gm. Jedwabne, woj. łomżyńskie, [w:] Informator Archeologiczny. Badania 1979, Warszawa 1980, s. 179.

29 Ibidem, s. 179-180. 
Prace wykopaliskowe z 1969 roku na grodzisku w Rajgrodzie (ryc. 2 i 3), ze względu na zakres badań i stan zachowania nawarstwień kulturowych, nie przyniosły jednoznacznych informacji potwierdzających hipotezy historyków o centralnej roli, jaką miał spełniać gród w organizacji terytorialnej południowej Jaćwieży ${ }^{30}$. Wpłynęły na to późniejsze dzieje „Góry Zamkowej”. W czasach Kazimierza Wielkiego miała się tu rozpocząć budowa zamku strzegącego północno-wschodniej rubieży Mazowsza. Musiało się to wiązać ze znacznymi pracami ziemnymi. Budowę rozpoczęto około 1360 roku, ale za sprawą najazdu krzyżackiego nie została ukończona ${ }^{31}$.

Wciąż trudną do jednoznacznego określenie funkcję w systemie osadniczym obszarów nadbiebrzańskich pełniło grodzisko w Grodziszczanach, zwane przez miejscową ludność „Okopem”, „Okopem szwedzkim” lub „Zamczyskiem” (fot. 1). Niewielkie grodzisko o średnicy majdanu około $25 \mathrm{~m}$, położone jest na krawędzi doliny bezimiennej strugi, której prawy brzeg stanowił dodatkowe zabezpieczenie grodu ${ }^{32}$. System obronny tworzyły dwa koncentryczne wały, przy czym wał zewnętrzny, znajdujący się jedynie od strony południowo-zachodniej i zachodniej, był znacznie niższy od wewnętrznego. Od zachodu relikt wału zewnętrznego kończy się na granicy dna doliny bezimiennej strugi, która otacza grodzisko od południowego-wschodu, wschodu i północnego-wschodu. Na tym odcinku rolę wału zewnętrznego pełniły zapewne rozlewiska tej strugi. Oba wały oddziela wąskie obniżenie. Brak jest śladów fosy zewnętrznej. Majdan grodziska jest wyraźnie wywyższony w części centralnej. Zarówno wały jak i majdan uległy znacznemu zniszczeniu na skutek użytkowania grodziska przez mieszkańców gospodarstwa zbudowanego w okresie międzywojennym w miejscu częściowo zniwelowanych wschodnich wałów. Najprawdopodobniej z tego względu we współczesnej topografii grodziska trudno jest wskazać, opisane przez Romana Jakimowicza, dookolne zagłębienie oddzielające majdan od wewnętrznego wału ${ }^{33}$.

\footnotetext{
30 A. Kamiński, Jaćwież..., s. 98-101; D. Jaskanis, Grodzisko w Rajgrodzie..., s. 80-81, 111-115.

31 A. Kamiński, Wizna..., s. 53. Wg Jerzego Wiśniewskiego zawartej w źródłach pisanych informacji o budowie zamku (?), podjętej na polecenie Kazimierza Wielkiego przez kasztelana wiskiego, nie można jednoznacznie wiązać z Rajgrodem. Inwestycja monarsza mogła zostać podjęta w odległości 3 mil od Rajgrodu (J. Wiśniewski, Dzieje osadnictwa w powiecie grajewskim do połowy XVI wieku [w:] Studia i materiaty do dziejów powiatu grajewskiego, Warszawa 1975, s. 27, przyp. 32). Wyniki badań archeologicznych nie pozostawiają jednak wątpliwości, że niezależnie od miejsca budowy zamku przez Kazimierza Wielkiego, „Góra Zamkowa” w Rajgrodzie była zamieszkiwana zarówno w średniowieczu jak i w czasach nowożytnych (por. D. Jaskanis, Grodzisko w Rajgrodzie..., s. 112-115).

32 R. Jakimowicz, Sprawozdanie z ..., s. 215.

33 Ibidem.
} 
Aleksander Kamiński wysunął hipotezę w myśl, której gród w Grodziszczanach osłaniał od południa terytorium Jaćwieży - ziemię Źlińców ${ }^{34}$. Hipotezy tej nie potwierdzają przeprowadzone tu dwukrotnie badania wykopaliskowe. Po raz pierwszy grodzisko sondował w 1929 r. Roman Jakimowicz. Przekop przez wał nie wykazał ,żadnego uwarstwienia”. Na majdanie znalezione zostały „,róg jelenia, jakieś dwa grzebienie, polepa, parę skorup”, w reliktach paleniska - dalsze fragment ceramiki, kości zwierzęce oraz kilka fragmentów żużla, z których jeden mógł być fragmentem „,rudy żelaznej” ${ }^{35}$. Wyniki badań nie zostały opublikowane. Kilkadziesiąt fragmentów naczyń ceramicznych odkrytych przez Romana Jakimowicza, Krystyna Musianowicz określiła jako „wczesnohistoryczne”36.

Po raz drugi prace wykopaliskowe na grodzisku w Grodziszczanach przeprowadzone zostały w 1986 r. pod kierownictwem Ludomira Łoźnego przez archeologów z Państwowego Muzeum Archeologicznego w Warszawie ${ }^{37}$. Trzy wy-

34 A. Kamiński, Jaćwież..., s. 98; tenże, Pogranicze..., s. 14.

35 A. Kamiński, Materiały..., s. 217.

36 Ibidem. Jednoznaczne określenie charakteru badań przeprowadzonych przez Romana Jakimowicza w 1929 r. na grodzisku w Grodziszczanach napotyka na niespodziewana przeszkodę, gdy poza publikacją Aleksandra Kamińskiego (A. Kamiński, Materiały..., s. 217) uwzględni się również dane archiwalne. W Archiwum Wojewódzkiego Urzędu Ochrony Zabytków w Białymstoku znajdują się dwa wyciagi z pism skierowanych przez Państwowe Grono Konserwatorów Zabytków Przedhistorycznych do Urzędu Wojewódzkiego w Białymstoku i przez Romana Jakimowicza do Konserwatora Zabytków. Pierwsze z nich datowane z dn. 30.IV.1929 r. zawiera jedynie lakoniczną informację o badaniach przeprowadzonych w 1922 r. na grodzisku w Grodziszczanach przez R. Jakimowicza. Natomiast pismo z dnia 27.V.1929 r. sygnowane przez Romana Jakimowicza zawiera informacje o wizytowaniu przez niego grodziska w Grodziszczanach w dniu 27.V.1929 r. W czasie wizytacji określił on powierzchnię grodziska wraz z przyległymi łąkami na 0,5 ha. Stwierdził też znaczne uszkodzenie zabytku przez jego właściciela Stanisława Miedziankę, polegające na rozkopaniu części zewnętrznego wału grodziska. Ziemia wydobyta $\mathrm{z}$ wału została rozwieziona na długości $28 \mathrm{~m}$. W czasie niwelacji wału zniszczeniu uległy również „,dwa pierwotne piece hutnicze", które znajdowały się na wewnętrznej stronie wału (Archiwum Wojewódzkiego Urzędu Ochrony Zabytków w Białymstoku, teczka X-1/10/66, Grodziszczany, gm. Dąbrowa Białostocka, relikty grodziska, AZP obszar 27-89, C-46). Nie można więc jednoznacznie ustalić, czy informacje o konstrukcji wału grodziska i zabytkach odkrytych na jego majdanie są efektem ratowniczych badań wykopaliskowych podjętych przez R. Jakimowicza po częściowym zniszczeniu grodziska, czy też zostały zebrane w wyniku obserwacji odsłoniętych przez zniszczenia nawarstwień. W innym miejscu Aleksander Kamiński podaje, że Roman Jakimowicz badał grodzisko w Grodziszczanach jedynie powierzchniowo (A. Kamiński, Pogranicze..., s. 14).

37 Badania miały charakter ratowniczy. Finansował je Konserwator Zabytków Archeologicznych na województwo białostockie (L. Loźny, Grodziszczany st. I. Sprawozdanie z badań w 1986 r., maszynopis w Archiwum Wojewódzkiego Urzędu Ochrony Zabytków w Białymstoku, teczka X-1/10/66; tenże Sprawozdanie z badań wykopaliskowych w Grodziszczanach, maszynopis w Archiwum Wojewódzkiego Urzędu Ochrony Zabytków w Białymstoku, teczka X-1/10/66, Grodziszczany, gm. Dąbrowa Białostocka, relikty grodziska, AZP obszar 27-89, C-46). Grodziszczany, [w:] Informator Archeologiczny. Badania 1986, Warszawa 1987, s. 125-126; K. Bieńkowska, $Z$ historii badań archeologicznych na Podlasiu, [w:] Stan badań archeologicznych na pograniczu polsko-białoruskim od wczesnego średniowiecza po czasy nowożytne, red. H. Karwowska, A. Andrzejowski, Białystok 2006, s. 12. 
kopy badawcze o łącznej powierzchni $63 \mathrm{~m}^{2}$ znajdowały się w północno-zachodniej, najmniej zniszczonej części grodziska, na majdanie przy wale i częściowo na wale wewnętrznym. Na majdanie odsłonięte zostały trzy warstwy związane najprawdopodobniej z funkcjonowaniem grodu: „zhumusowana, ciemnobrązowa ziemia”, „ciemnoszara ziemia, prawdopodobnie pozostałość warstwy kulturowej” i „fragmenty bruku kamiennego, dość luźnego"38. Z warstw tych pochodził niehomogeniczny zbiór fragmentów wczesnośredniowiecznej ceramiki naczyniowej. Autor badań stwierdził, że: „W większości jest to ceramika słowiańska, trudno jednak $\mathrm{w}$ tej chwili stwierdzić czy mazowiecka czy ruska, najprawdopodobniej jest to materiał mieszany" ${ }^{39}$. W niewielkim wykopie obejmującym część wału wewnętrznego odsłonięte zostały relikty konstrukcji wału. Ustalono, że tworzył go nasyp ziemny przykryty płaszczem glinianym, bez jakichkolwiek konstrukcji drewnianych lub kamiennych ${ }^{40}$. Na podstawie chronologii odkrytych fragmentów naczyń glinianych datowanie grodziska w Grodziszczanach ustalono na XI-XIII w. ${ }^{41}$

Znane jedynie z poszukiwań powierzchniowych grodzisko we wsi Grodzisk, gm. Suchowola, zwane „Wał”, położone jest na północ od drogi do wsi vis a vis współczesnego cmentarza ${ }^{42}$. Aleksander Kamiński wiązał je hipotetycznie z terytorium plemiennym jaćwieskich Zlińców ${ }^{43}$ i podał, że był to gród o niemal kolistym majdanie o średnicy około $45 \mathrm{~m}$, otoczony dwoma wałami oddzielonymi fosą, przy czym w pełni zachował się tylko wał wewnętrzny ${ }^{44}$. W rzeczywistości umocnienia grodu składały się z wału ziemnego o bliżej nieokreślonej konstrukcji, którego relikty w części północnej, północno-wschodniej i wschodniej osiągają dziś jeszcze 5-6 m. Na koronie wału widoczne są pojedyncze kamienie z jego konstrukcji. Od południowego - zachodu w wale znajduje się obniżenie - pozostałość bramy.

38 L. Łoźny, Grodziszczany st. I...; tenże Sprawozdanie...; Grodziszczany..., s. 125-126.

39 Ibidem.

40 Ibidem. Odmienne informacje o wynikach badań wykopaliskowych przeprowadzonych przez Ludomira Łoźnego w 1986 r. na grodzisku w Grodziszczanach podaje Krystyna Bieńkowska. W przekopie przez wał miała zostać odsłonięta konstrukcja przekładkowa wzmocniona od zewnątrz kamieniami. Natomiast fragmenty naczyń ceramicznych miały wykazywać „dużą zbieżność" z ceramiką odkrytą w Drohiczynie. Jako źródło informacji autorka wskazała Informator Archeologiczny (K. Bieńkowska, Z historii badań..., s. 12; Grodziszczany..., s. 125-126). Na użycie kamieni do budowy (wzmocnienia?) wewnętrznego wału może wskazywać skupisko dużych kamieni polnych znajdujące się współcześnie na wale od strony południowo-wschodniej. Najprawdopodobniej również wał zewnętrzny miał konstrukcję ziemną, przykrytą płaszczem glinianym. Wskazuje na to struktura tego wału odsłonięta w osuwisku w jego południowo-wschodniej części.

41 Grodziszczany..., s. 125.

42 R. Jakimowicz Sprawozdanie z ..., s. 214.

43 A. Kamiński, Jaćwież..., s. 98.

44 A. Kamiński, Materiały..., s. 216; tenże, Pogranicze..., s. 14. 
$\mathrm{Na}$ wschód od grodziska, bezpośrednio przy wale, rozciąga się skraj rozległej, podmokłej doliny strugi zwanej Młynek, wpadającej do jednego z lewobrzeżnych dopływów Biebrzy. Stanowiła ona dodatkowe zabezpieczenie grodu. Natomiast od południa, zachodu i północy, równolegle do wału głównego, biegnie niski wał zewnętrzny o wysokości nieprzekraczającej $1-1,5 \mathrm{~m}$ i szerokości ok. 2 m, oddzielony od wału głównego wąskim i płytkim obniżeniem - pozostałością suchej fosy. Szerokość fosy nie przekracza $2 \mathrm{~m}$. Wał zewnętrzny zaczynał się bezpośrednio na wschód i zachód od obniżenia bramnego w wale głównym i dochodził od południowego wschodu i północnego wschodu do podmokłej doliny strugi na wschód od grodziska. Wał ten musiał być zwieńczony palisadą, gdyż sam z siebie nie stanowił istotnej przeszkody terenowej.

Współcześnie majdan grodziska jest nierówny. Jego zasadnicza część jest mocno wypiętrzona. Otacza ją biegnące przy wale dookolne obniżeniem. W obniżeniu widoczne są liczne ślady wkopów, z których przynajmniej część istniała już w latach dwudziestych XX wieku ${ }^{45}$. W południowej i centralnej części majdanu w warstwie humusu tkwią trzy średniej wielkości kamienie mogące stanowić pozostałość fundamentu budynku. Relacja wysokości wału do poziomu majdanu wskazuje, że wznosząca się tu zabudowa musiała być widoczna spoza wału, zakładając, że nie posiadał on dodatkowego zwieńczenia.

Współczesna droga gruntowa prowadząca od szosy do grodziska biegnie prosto do obniżenia bramnego $\mathrm{w}$ wale i jest najprawdopodobniej reliktem starej drogi lub grobli. Droga ta ma szerokość 3-4 m i jest wypiętrzona ponad otaczające ją łąki na około $10-15 \mathrm{~cm}$. Liczne kamienie widoczne wśród darni są najprawdopodobniej pozostałością bruku.

Obecnie, grodzisko i otaczający je teren użytkowane są jako pastwiska, co praktycznie uniemożliwia prowadzenie poszukiwań powierzchniowych. W 1923 roku grodzisko badał powierzchniowo Roman Jakimowicz, odnajdując tu fragmenty naczyń średniowiecznych i ułamek naczynia szklanego ${ }^{46}$. W latach pięćdziesiątych XX wieku, Aleksander Kamiński zebrał z powierzchni grodziska i „podgrodzia”, znajdującego się jego zdaniem na zachód od grodu, zbiór fragmentów pochodzących z naczyń nieornamentowanych oraz zdobionych dookolnymi żłobkami, które datował na XIII wiek. W zbiorze tym znalazło się też kilka ułamków naczyń o późniejszej - czternastowiecznej chronologii ${ }^{47}$. Z dużym

\footnotetext{
45 R. Jakimowicz, Sprawozdanie z ..., s. 215.

46 Ibidem, s. 214-215.

47 A. Kamiński, Pogranicze..., s. 15. Miejsce przechowywania zabytków z badań powierzchniowych prowadzonych przez Aleksandra Kamińskiego nie jest znane autorowi. Jednak na podstawie zamieszczonego w publikacji (A. Kamiński, Pogranicze..., s. 14-15) opisu odkrytych wówczas fragmentów wydaje się, że ich chronologia była nieco późniejsza i odpowiadała okresowi późnego średniowiecza i czasom wczesnonowożytnym.
} 
prawdopodobieństwem można przyjąć, że grodziską pod wsią Grodzisk badane było również wykopaliskowo. Pozostałością tych badań może być wąskie, poprzeczne zaklęśnięcie w północnej części wału głównego. W literaturze brak jest jakichkolwiek wzmianek o tych badaniach w związku z czym ich autor i wyniki są nieznane.

Kolejne informacje o grodzisku zebrane zostały podczas badań powierzchniowych i inspekcji konserwatorskich przeprowadzonych w ciągu ostatnich trzydziestu lat. Badania powierzchniowe Archeologicznego Zdjęcia Polski, dostarczyły fragmentów ceramiki datowanej na XII-XIII w., oraz XVI-XVII w.48 Z kolei w 2006 r. na majdanie grodziska odnalezione zostały fragmenty naczyń z IX-X w., XI-XIII w. i nowożytnych oraz polepa konstrukcyjna i fragmenty

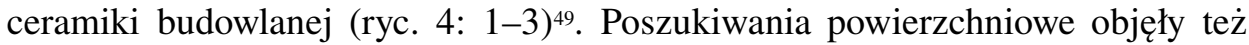
znajdujące się na północ, zachód i południe od grodziska relikty osady otwartej, gdzie również natrafiono na fragmenty naczyń wczesnośredniowiecznych, oraz nowożytnych z XVI-XVII w., a także fragmenty kafli piecowych i naczyń szklanych (ryc. 4: 4-8; ryc. 5) ${ }^{50}$.

Informacji o szczegółach konstrukcyjnych wału wewnętrznego grodziska pod wsią Grodzisk dostarczyła z kolei wizytacja konserwatorska przeprowadzona w 1997 r. W części wału uszkodzonej przez wybieranie gliny, poza cienką warstwą spalenizny nie stwierdzono śladów konstrukcji drewnianej lub kamiennej. Nie natrafiono w nim też na materiał zabytkowy ${ }^{51}$.

Równie liczną - jak grodziska - kategorię stanowisk archeologicznych na obszarach nadbiebrzańskich, stanowią cmentarzyska. Ze względu na formę grobu - obstawy kamienne, stele lub nasyp kurhanowy oraz typ pochówku - szkieletowy, najczęściej odkrywane były cmentarzyska wczesnośredniowieczne, a także późnośredniowieczne i wczesnonowożytne. W sumie z interesującego nas obszaru znanych jest trzynaście cmentarzysk. Należą do nich: dwa kurhany pod

48 Badania powierzchniowe metodą Archeologicznego Zdjęcia Polski przeprowadził 15.11.1989 r. Dariusz Krasnodębski (teczka AZP 27-86 w Archiwum Wojewódzkiego Urzędu Ochrony Zabytków w Białymstoku).

49 Obszar grodziska wizytowany był przez autora i Małgorzatę Karczewską 8.04.2006 r. Na materiał zabytkowy natrafiono w kretowinach w północnej i północno-wschodniej części majdanu. Zabytki znajdują się w zbiorach Instytutu Historii Uniwersytetu w Białymstoku.

50 Badania powierzchniowe metodą Archeologicznego Zdjęcia Polski przeprowadził 15.11.1989 r. Dariusz Krasnodębski (teczka AZP 27-86 w Archiwum Wojewódzkiego Urzędu Ochrony Zabytków w Białymstoku). Ósmego kwietnia 2006 r. teren osady wizytowany był przez autora i Małgorzatę Karczewską. Zabytki odnalezione na powierzchni oranej części osady znajdują się w zbiorach Instytutu Historii Uniwersytetu w Białymstoku.

51 Wizytacja przeprowadzona została w dn. 22.05.1997 r. przez Krystynę Bieńkowską, Jerzego Maciejczuka i Katarzynę Rusin (teczka X-1/8/66, C-56, Grodzisk, gm. Suchowola, grodzisko, AZP obszar 27-86, w Archiwum Wojewódzkiego Urzędu Ochrony Zabytków w Białymstoku). 
wsią Okopy (fot. 2) ${ }^{52}$, cmentarzysko kurhanowe we wsi Kąty, wczesnośredniowieczne cmentarzyska typu mazowieckiego z grobami w obstawach kamiennych znane z: Jacewka, Jedwabnego, Kokoszek, Kotowa, Pieńków Grodziska, Rostków Małych, Rusi, cmentarzyska szkieletowe na piaskach miejskich w Suchowoli, i pod wsią Wilamówka - nowożytne (?), oraz cmentarzyska ze stelami kamiennymi, niekiedy znaczonymi wyciosanym znakiem krzyża w Jatwieży Małej (fot. 3) i Zabielach ${ }^{53}$. Zawierające kamienie nasypy kurhanów oraz kamienne konstrukcje grobów typu mazowieckiego i stele były jedną $\mathrm{z}$ istotnych przyczyn masowego niszczenia tej kategorii stanowisk archeologicznych w 2. połowie XIX i w początkach XX wieku. Wydobywany z nich kamień używany był jako łatwo dostępny materiał do budowy dróg. $\mathrm{Z}$ tego powodu należy liczyć się z możliwością całkowitego zniszczenia części wczesnośredniowiecznych, późnośredniowiecznych i wczesnonowożytnych cmentarzysk, zanim informacja o nich dotarła do archeologów.

Poza stanowiskiem nr 2 we wsi Grodzisk, stanowiska archeologiczne kryjące w sobie relikty osiedli otwartych, nie były znane na obszarach nadbiebrzańskich do chwili rozpoczęcia badań metodą Archeologicznego Zdjęcia Polski ${ }^{54}$. Związek $\mathrm{z}$ osadnictwem, najprawdopodobniej średniowiecznym lub nowożytnym, miały natomiast „starożytne drogi - groble” pod wsiami Jagłowo i Mikicin. Do pojedynczych odkryć znad Biebrzy należy zaliczyć również wczesnośredniowieczny skarb ze Strękowej Góry i zbiór zabytków z okresu wpływów rzymskich, pochodzących najprawdopodobniej ze zniszczonego cmentarzyska, zebranych z wydmy pod Osowcem ${ }^{55}$.

52 Opisując kurhany pod wsią okopy Roman Jakimowicz nie wypowiedział się na temat ich chronologii (R. Jakimowicz, Sprawozdanie z ..., s. 213). Aleksander Kamiński podaje, że jest to „cmentarzysko z okresu przedpiastowskiego” (A. Kamiński, Materiały..., s. 235). Na podstawie wyników badań wykopaliskowych Danuta Jaskanis uznała jeden z nich za wczesnośredniowieczny (D. Jaskanis, Kurhan w Okopach, pow. Dąbrowa Białostocka, „Rocznik Białostocki”, t. VIII, 1968, s. $410-412$.

53 R. Jakimowicz, Sprawozdanie z ..., s. 213, 214.

54 Relikty osad otwartych są najbardziej masową kategorią stanowisk archeologicznych odkrywanych podczas badań powierzchniowych prowadzonych metodą Archeologicznego Zdjęcia Polski.

55 Aleksander Kamiński podaje, że w archiwum Państwowego Muzeum Archeologicznego znajdowała się notatka dotycząca jednego pudła zabytków metalowych ,zebranych w 1933 r. przez Płońskiego ze środka dużej wydmy na północ od szosy Osowiec - Goniądz, $1 \mathrm{~km}$ na północ od Biebrzy, $120 \mathrm{~m}$ od głównej twierdzy w Osowcu". Ta sama notatka określała ich chronologię na „Okres rzymski?" Zabytki zinwentaryzowane były pod numerem inwentarza 197 (A. Kamiński, Materiały..., s. 237). Współcześnie w zbiorach PMA brak tych zabytków. Być może zaginęły one wraz z połową zbiorów tego muzeum w czasie II wojny światowej (teczka 31 „Artykuł o stratach PMA w czasie wojny" Archiwum Jerzego Antoniewicza w Dziale Archeologii Muzeum Warmii i Mazur w Olsztynie. Artykuł autorstwa J. Antoniewicza o stratach PMA nigdy nie ukazał się drukiem - porównaj: B. Antoniewicz, Wykaz prac opublikowanych i edytorskich Jerzego Antoniewicza za lata 1945-1970, „Komunikaty Mazursko-Warmińskie”, nr 4 (110), 1970, s. 679-685; taż, 
Zestawienie wyników poszukiwań i badań archeologicznych oraz odkryć przypadkowych, jakie miały miejsce na obszarach nadbiebrzańskich od połowy XIX wieku do końca lat siedemdziesiątych XX wieku przynosi szczególny i zupełnie nieprawdziwy obraz zasiedlania tych terenów w pradziejach i czasach historycznych. Do wczesnego średniowiecza, poza zbiorem zabytków z dwóch zniszczonych cmentarzysk datowanych prawdopodobnie na okres wpływów rzymskich: pod Osowcem i pod Szafrankami ${ }^{56}$, nie dysponujemy śladami osadnictwa z wczesnej epoki żelaza, okresu wpływów rzymskich i okresu wędrówek ludów. Czasy wczesnego średniowiecza reprezentowane są przez grodziska i cmentarzyska, przy niemal zupełnym braku śladów osiedli otwartych. Podobnie rzecz się ma z późnym średniowieczem i nowożytnością. W tym przypadku znane są pojedyncze cmentarzyska ze stelami kamiennymi i cmentarzysko szkieletowe odkryte pod Suchowolą, dwie „starożytne groble” i najprawdopodobniej trzy „grodziska” - pod wsią Grodzisk, w Grodziszczanach i „Pobojna Góra” pod wsią Czarniewo.

Ogromny, ilościowi przyrost stanowisk archeologicznych odkrytych na terenach nadbiebrzańskich przyniosły badania powierzchniowe prowadzone $\mathrm{w}$ ramach Archeologicznego Zdjęcia Polski (AZP). Podstawy teoretyczne metody zostały opracowane w latach 1970-198057. Realizacja AZP miała trzy cele: „1. naukowo-badawczy (skompletowanie wiedzy o rzeczywistej liczebności i dystrybucji w terenie stanowisk archeologicznych), 2. konserwatorski (w warunkach

\footnotetext{
Bibliografia prac Jerzego Antoniewicza, „Rocznik Mazowiecki”, t. IV, 1972, s. 461-468; Wykaz prac opublikowanych i edytorskich Jerzego Antoniewicza za lata 1945-1970, [w:] J. Antoniewicz, Bałtowie zachodni, Olsztyn - Białystok 1979, s. 229-236). Możliwe jest również, że Aleksander Kamiński uzyskał nieprecyzyjną informację. Obecnie w zbiorach Działu Archeologii Bałtów PMA znajdują się: mały, kulisty paciorek z niebieskiego szkła, fragment blaszki brązowej i fragment trzpienia brązowego odkryte w 1933 r. w Osowcu (nr inw. PMA/IV/6925). Być może są to zabytki cytowane wcześniej przez Aleksandra Kamińskiego. Dziękuję dr Annie Bitner-Wróblewskiej kierownikowi Działu Archeologii Bałtów PMA za informację o wymienionych zabytkach.

56 Relikty tego cmentarzyska odkryli Zygmunt Gloger i Ludwik de Fleury w 1879 r. Na wydmie położonej „,1/2 mili od Goniądza, na północny-zachód od wsi Szafranki, o kilkaset kroków od koryta rzeki” wśród zabytków krzemiennych odnaleźli oni również „kości ludzkie palone” i „trzpień brązowy, płaski" od sprzączki do pasa (Z. Gloger, Osady przedhistoryczne na porzeczu Biebrzy, „Zbiór Wiadomości do Antropologii Krajowej”, t. IV, dział I, 1882, s. 2). Być może również z tego cmentarzyska pochodziła odkryta w 1933 r. szpila brązowa wykonana z częśsi szczypczyków (M. Kaczyński, Interesujące znalezisko z miejscowości Goniądz - Szafranki, pow. Mońki, „Wiadomości Archeologiczne”, t. XXXVI, z. 3, 1971, s. 355-356). Ze względu na brak precyzyjnego określenia miejsc odkryć ich weryfikacja nie jest możliwa. Cały obszar na zachód od Szafranek, na przestrzeni między dnem Kotliny Biebrzańskiej i podmokłymi łąkami położonymi na południe od wsi i na północ od szosy do Goniądza, jest zwydmiony i częściowo porośnięty młodym lasem sosnowym. Odsłonięte części wydm są mocno zniszczone przez wybieranie piasku.

57 M. Konopka, Instrukcja ewidencji stanowisk archeologicznych metodq badań powierzchniowych (Archeologiczne Zdjęcie Polski), Warszawa 1984, s. 6.
} 
intensywnego uprzemysłowienia kraju i przyśpieszonej erozji gleb oraz mnożących się robót ziemnych niezbędne jest, aby z racjonalnym wyprzedzeniem móc podejmować działalność zabezpieczająca), 3. popularyzatorski (pomnożenie archeologicznych zasobów źródłowych jako przesłanki działalności popularyzatorsko-muzealnej, kształtującej społeczną wiedzę o pradziejach i wczesnej historii ziem polskich)" 58 . W ciągu niemal trzech dekad badań prowadzonych metodą AZP ${ }^{59}$ nie udało się osiągnąc zakładanej, pełnej porównywalności ich wyników. Wpłynęły na to zarówno kłopoty z prawidłowym sporządzaniem dokumentacji z badań ${ }^{60}$, jak też modyfikacje tej dokumentacji wprowadzane już w trakcie realizacji AZP oraz „komercyjne” podejście wielu wykonawców do prowadzonych badań ${ }^{61}$. Od początku nie przestrzegano też części założeń metody. Przede wszystkim nie zrealizowano kompleksowej kwerendy archiwalnej dla poszczególnych województw, która miała wyprzedzić realizację badań terenowych $^{62}$. Ubóstwo archiwów konserwatorskich $\mathrm{w}$ zestawieniu $\mathrm{z}$ różnym poziomem przygotowania uczestników badań spowodowały, że w niektórych przypadkach kwerenda ta nie była wykonywana lub nie obejmowała wszystkich koniecznych zbiorów i archiwów.

Odrębnym problemem pozostaje reprezentatywność wyników badań AZP w stosunku do rzeczywistego obrazu osadnictwa pradziejowego i historycznego na danym obszarze. Zakładana pełna wykrywalność stanowisk archeologicznych, manifestujących się poprzez występowanie materiału zabytkowego na powierzchni gruntu, w praktyce jest niemal niemożliwa do osiągnięcia. Mają

58 A. Kempisty, J. Kruk, S. Kurnatowski, R. Mazurowski, J. Okulicz, T. Rysiewska, S. Woyda, Projekt założeń metodyczno - organizacyjnych archeologicznego zdjęcia ziem polskich, [w:] Zdjęcie Archeologiczne Polski, red. M. Konopka, Biblioteka Muzealnictwa i Ochrony Zabytków, Seria B, t. LXVI, Warszawa 1981, s. 22.

59 Realizację programu AZP rozpoczęto w 1978 roku.

60 Podstawową dokumentacją z badań AZP jest Karta Ewidencji Stanowiska Archeologicznego i mapa obszaru AZP z zaznaczonymi wszystkimi stanowiskami archeologicznymi znanymi z kwerendy archiwalnej i odkrytymi podczas badań powierzchniowych.

61 D. Jaskanis, Ewidencja archeologicznych dóbr kultury. I. Komentarz do instrukcji ewidencji stanowisk archeologicznych metodq badan powierzchniowych (Archeologiczne Zdjęcie Polski) z 1984 r. II. Zasady prowadzenia ewidencji archeologicznej w miastach, [w:] Ewidencja, eksploracja i dokumentacja w praktyce konserwatorstwa archeologicznego, red. Z. Kobyliński, Zeszyty Generalnego Konserwatora Zabytków. Archeologia, z. 1, Warszawa 1998, s. 15-45; M. Konopka, Komentarz do Instrukcji wypetniania Karty Ewidencji Stanowiska Archeologicznego AZP, Warszawa (powielone); idem, Instrukcja...; J. Jaskanis, Organizacyjne aspekty działalności archeologów w Polsce powojennej - próba oceny, [w:] Archeologia i prahistoria polska w ostatnim pótwieczu. Materiały z konferencji „Dorobek polskiej archeologii i prahistorii ostatniego półwiecza” w Puszczykowie koło Poznania (27-30 października 1997 r.), red. M. Kobusiewicz, St. Kurnatowski, Poznań 2000, s. 557.

62 A. Kempisty, J. Kruk, S. Kurnatowski, R. Mazurowski, J. Okulicz, T. Rysiewska, S. Woyda, Projekt założeń..., s. 25-26. 
na to wpływ z jednej strony dostępności terenu i warunki obserwacji (stosunek pól uprawnych do łąk i nieużytków, stopień przemycia gleby i stan zaawansowania wegetacji roślin), z drugiej zaś rzetelność przeprowadzenia samych badań63. Wielce wymowne w tym względzie może być porównanie wyników badań AZP przeprowadzonych na sąsiadujących ze sobą obszarach o zbliżonych warunkach fizjograficznych.

Kolejne ograniczenie przydatności stanowisk archeologicznych rozpoznanych wyłącznie w wyniku AZP do badań nad pradziejami i okresem historycznym jest fragmentaryczność źródeł i wynikające stąd problemy z określeniem ich chronologii oraz funkcji stanowiska w systemie osadniczym ${ }^{64}$. Podstawowym materiałem zabytkowym odkrywanym na stanowiskach $\mathrm{z}$ epoki żelaza są fragmenty ceramiki naczyniowej. Ich rozdrobnienie i często zły stan zachowania nie pozwalają na wykorzystanie tradycyjnych metod ustalania chronologii tej kategorii zabytków, odwołujący się do zróżnicowania ornamentyki i form naczyń oraz sposobu opracowania ich powierzchni. Wynika stąd konieczność niekiedy bardzo szerokiego datowania zabytków, a w konsekwencji również stanowisk archeologicznych, z których pochodzą. Co więcej, dla niektórych okresów materiały takie są trudne do rozpoznania. Sprzyja to powstawaniu swoistych „pustek” osadniczych. Problem ten dobrze ilustrują stanowiska wczesnośredniowieczne odkryte podczas AZP na obszarach nadbiebrzańskich. Ich chronologia określana jest zazwyczaj ogólnie jako „wczesnośredniowieczna”, rzadziej „X-XIII wiek” lub „XI-XIII wiek”, przy czym podstawy tych określeń są najczęściej takie same ${ }^{65}$. W związku z tym nie udało się dotychczas odkryć stanowisk reprezentujących w sposób pewny najwcześniejsze fazy wczesnego średniowiecza. Stanowiska takie odegrałyby kluczową rolę w badaniach nad przemianami kulturowymi u schyłku antyku i początkiem formowania się wczesnośredniowiecznego pogranicza bałto-słowiańskiego na obszarze Polski północno-wschodniej.

Obszar Kotliny Biebrzańskiej i jej najbliższą okolicę pokrywa 55 obszarów AZP. Badania powierzchniowe metodą AZP podjęto tu po raz pierwszy

63 Por.: J. Jaskanis, Organizacyjne aspekty..., s. 557.

${ }^{64}$ L. Czerniak, Archeologiczne Zdjęcie Polski - co dalej?, [w:] Archeologiczne Zdjęcie Polskimetoda i doświadczenia. Próba oceny, red. D. Jaskanis, Biblioteka Muzealnictwa i Ochrony Zabytków, Seria B, t. XCV, Warszawa 1996, s. 39-40; S. Kurnatowska, Z. Kurnatowski, Uwagi o AZP z perspektywy badań w Wielkopolsce, [w:] Archeologiczne Zdjęcie Polski - metoda i doświadczenia. Próba oceny, red. D. Jaskanis, Biblioteka Muzealnictwa i Ochrony Zabytków, Seria B, t. XCV, Warszawa 1996, s. 80; Matoga, Archeologiczne Zdjęcie Polski - połowa drogi, [w:] Archeologiczne Zdjęcie Polski - metoda i doświadczenia. Próba oceny, red. D. Jaskanis Biblioteka Muzealnictwa i Ochrony Zabytków, Seria B, t. XCV, Warszawa 1996, s. 49.

65 Chodzi tu o cechy technologiczne naczyń związane z wczesnośredniowiecznym przełomem w garncarstwie oraz - rzadziej - sposób zdobienia w formie linii falistej, dookolnych żłobków lub kombinacji tych dwóch wątków. 
w 1983 roku. Do 2006 roku zbadano 54 obszary (ryc. 6). Pod względem ilościowym stan realizacji przeprowadzonych tu badań powierzchniowych można więc uznać za wzorcowy. Znacznie gorzej przedstawia się jakościowa ocena tych badań. Analiza dokumentacji zgromadzonej w archiwach konserwatorskich na obszarze województwa podlaskiego ${ }^{66}$ wykazała aktualność wszystkich wymienionych wyżej zastrzeżeń dotyczących metody i sposobu realizacji AZP. Zdaniem autora znaczna część obszarów AZP zbadanych nad Biebrzą do 1988 roku wymaga weryfikacji ${ }^{67}$. Jako przyczynę niekiedy zastanawiająco małej liczby stanowisk odnalezionych podczas prospekcji terenowej na tych obszarach, nie zawsze da się wskazać złe warunki obserwacji wynikające z dużego areału łąk, nieużytków i lasów lub zbyt późnego terminu badań i związanej z nim zaawansowanej wegetacji roślin ${ }^{68}$.

Przedstawione uwagi na temat ograniczeń metody AZP oraz stanu realizacji tych badań na obszarach nadbiebrzańskich wskazują, że pomimo znacznej liczby stanowisk archeologicznych rozpoznanych tą drogą, nie stanowią one wystarczającej bazy źródłowej do badań nad zasiedlaniem i przemianami kulturowymi w skali całego obszaru. Pomimo to, nawet przy wszystkich wskazanych ograniczeniach, są one niezwykle cennym źródłem - niekiedy jedynym śladem osadnictwa $\mathrm{z}$ danego odcinka dziejów. Badania AZP przynoszą też rozstrzygnięcie problemów $\mathrm{z}$ okresów $\mathrm{w}$ pełni historycznych, weryfikując informacje zawarte w źródłach pisanych, jak też interpretację tych źródeł zawartą w pracach historyków.

\section{Dzieje zasiedlania Kotliny Biebrzańskiej w epoce żelaza}

Przystępując do próby przedstawienia zarysu dziejów zasiedlania Kotliny Biebrzańskiej w epoce żelaza, należy uwzględnić w jak najszerszym zakresie stan wiedzy archeologicznej o przeszłości terenów sąsiednich - Równiny Augustowskiej, południowej części Pojezierza Ełckiego i części Niziny Podlaskiej na północ od Narwi. Wpływa na to ograniczona liczba źródeł archeologicznych

\footnotetext{
66 Dokumentacja z badań AZP znajduje się w archiwach: Podlaskiego Wojewódzkiego Konserwatora Zabytków w Białymstoku, oraz Łomżyńskiej i Suwalskiej Delegatury Służby Ochrony Zabytków. Podział dokumentacji (i zabytków) z badań AZP między trzy ośrodki odzwierciedla dawny podział administracyjny kraju i ówczesną strukturę Służby Ochrony Zabytków na terenie byłych województw białostockiego, łomżyńskiego i suwalskiego.

67 Chodzi tu o obszary AZP nr: 26-86, 26-88, 28-81, 28-82, 29-80, 29-81, 29-82, 30-80, $30-81,30-82$, 30-83, 31-80, 31-81, 32-79, 32-80, 33-79, 33-80, 34-80, 34-81, 35-79, 35-81, $36-82$.

68 Problem jakości realizacji badań w ramach AZP na obszarach nadbiebrzańskich został dostrzeżony już wcześniej - por. dokumentację z badań AZP na obszarach AZP 29-83 i 36-79 w archiwum Podlaskiego Wojewódzkiego Konserwatora Zabytków.
} 
odkrytych ja dotąd w Kotlinie Biebrzańskiej oraz specyficzna rola przypisywana Biebrzy w podejmowanych dotychczas studiach nad dziejami obszaru dzisiejszej Polski północno-wschodniej w epoce żelaza.

Rozpoznana dotychczas sytuacja kulturowo-osadnicza w ostatnich pięciu wiekach przed naszą erą na obszarach położonych na północ i południe od Kotliny Biebrzańskiej wskazuje, że Biebrza była wówczas osią rozległej pustki osadniczej. Na północy strefę graniczną tej pustki wyznaczały stanowiska archeologiczne z południowej części Pojezierza Ełckiego i Suwalszczyzny ${ }^{69}$. W części zachodniej są to stanowiska związane z kulturą kurhanów zachodniobałtyjskich, we wschodniej zaś z wpływami kultury ceramiki kreskowanej. Prace wykopaliskowe, które dostarczyły zabytków z tego okresu przeprowadzone zostały na „Górze Zamkowej” w Rajgrodzie. W 1916 roku niemiecki archeolog Bruno Erlich znalazł tu fragmenty naczyń ceramicznych z ,epoki halsztackiej”70. Dalsze fragmenty naczyń z wczesnej epoki żelaza, niestety zalegające poza pierwotnym kontekstem stratygraficznym, zostały odkryte podczas prac wykopaliskowych prowadzonych na tym stanowisku w 1969 roku. Autorka badań słusznie wskazuje, że ceramika ta reprezentuje cechy charakterystyczne dla kultury kurhanów zachodniobałtyjskich ${ }^{71}$. Prawdopodobna jest też hipoteza, w myśl której znaleziska z Rajgrodu są śladem zasiedlania wschodnich Mazur i Suwalszczyzny we wczesnej epoce żelaza przez ludność przybywającą z dwóch kierunków. Z zachodu, z obszaru kultury kurhanów zachodniobałtyjskich, co potwierdziły odkrycia z „Góry Zamkowej” w Rajgrodzie, oraz ze wschodu, z obszaru kultury ceramiki kreskowanej ${ }^{72}$. Nieliczne relikty osiedli tej ludności, posługującej się naczyniami o charakterystycznie ,zakreskowanych” powierzchniach, odkryto jak dotąd na kilku stanowiskach na wschodniej Suwalszczyźnie - na dwóch osadach w Żubronajciach i na osadzie w Posejnelach ${ }^{73}$. Alternatywną hipotezą jest

69 Porównaj: mapę „Stanowiska kultury kurhanów zachodniobałtyjskich we wczesnej epoce żelaza” w pracy Łucji Okulicz (Ł. Okulicz, Kultura kurhanów zachodniobałtyjskich we wczesnej epoce żelaza, Wrocłąw - Warszawa - Kraków 1970); katalog i mapę osadnictwa południowo-wschodniej strefy nadbałtyckiej w I tysiącleciu p.n.e. w pracy Mirosława Jerzego Hoffmanna (M. J. Hoffmann, Źródła do kultury i osadnictwa południowo-wschodniej strefy nadbattyckiej w I tysiacleciu p.n.e., Olsztyn 1999), oraz mapy: „Osadnictwo południowo-wschodniej strefy nadbałtyckiej w II fazie (HaD-LtB)” i „Osadnictwo południowo-wschodniej strefy nadbałtyckiej w III fazie (młodszy okres przedrzymski) w pracy tegoż autora (M. J. Hoffmann, Kultura i osadnictwo południowo-wschodniej strefy nadbattyckiej w I tysiacleciu p.n.e., Olsztyn 2000, mapa IV, V).

70 B. Erlich, Der Schlossberg..., s. 35.

71 D. Jaskanis, Grodzisko w Rajgrodzie..., s. 112, 115-116.

72 Ibidem, s. 115-116.

73 J. Jaskanis, Jaćwież w badaniach archeologicznych. Stan i perspektywy badawcze, „Rocznik Białostocki", t. XIV, 1981, s. 51, 59; P. Szymański, Żubronajcie - przyczynek do badań nad wczesnożelazna ceramika Suwalszczyzny, [w:] Ceramika zachodniobattyjska od wczesnej epoki żelaza do poczq̨tku ery nowożytnej. Materiały z konferencji - Białystok 14-16 maja 1997, red. 
wskazanie na istnienie na wschodniej Suwalszczyźnie i na obszarach między Biebrzą i Narwią niezdefiniowanej jeszcze jednostki kulturowej, której jednym z wyznaczników są naczynia o powierzchni zewnętrznej pokrytej kreskowaniem. Jednostka ta rozwijała się w szerokich ramach chronologicznych od wczesnej epoki żelaza po okres wpływów rzymskich na pograniczu kultur Europy Środkowej i Wschodniej ${ }^{74}$.

W tym samym czasie - tj. w okresie halsztackim - obszary położone na południe od Biebrzy nie były zasiedlone aż do strefy nadbużańsko-nadnarwiańskiej, która wyznaczała północną granicę zasięgu zarówno grupy mazowiecko - podlaskiej kultury łużyckiej, jak i następującej po niej kultury pomorskiej (ewentualnie kultury grobów kloszowych) ${ }^{75}$. Analogiczna sytuacja miała również miejsce w okresie przedrzymskim. Stanowiska kultury przeworskiej sięgały w kierunku północno-wschodnim do obszarów nad dolną Narwią ${ }^{76}$.

Przedstawiony obraz sytuacji kulturowo-osadniczej we wczesnej epoce żelaza może ulec modyfikacji, gdy uwzględni się wyniki badań AZP. Dotychczas ślady osadnictwa $\mathrm{z}$ tego okresu odkryte zostały nad dolną Biebrzą w Sieburczynie stanowisko 2 (AZP 35-80), nad środkową Biebrzą w Horodniance stanowisko III (AZP 26-86), Dolistowie Starym, stanowisko 41, Dolistowie Nowym stanowisko 42, Kopytkowie stanowisko 2 (AZP 28-84), Laudańszczyźnie stanowisko 1 (AZP 27-86), nad górną Biebrzą w Hanulce stanowisko 10, Kuderowszczyźnie stanowisko 1 i Małyszówce stanowisko 4 (AZP 26-87), w Jacznie stanowisko VI oraz Kolonii Chilmony stanowiska I i V (AZP 26-89), nad Olszanką - dopływem Brzozówki i Biebrzy w Brukowie stanowisko 2 i Krzywej stanowisko 1 (AZP 28-85), nad Brzozówką w Karpowiczach stanowisko 7 (AZP 28-85) oraz

\footnotetext{
M. Karczewski, Białystok 1998, s. 118. Listę stanowisk archeologicznych z wczesnej epoki żelaza odkrytych na północ od Biebrzy uzupełnić można o ślady osadnictwa z tego okresu odkryte na stanowisku 1 w Woźnej Wsi (E. Kempisty, Z. Sulgostowska, Osadnictwo paleolityczne, mezolityczne i paraneolityczne $w$ Woźnej Wsi, woj. łomżyńskie, Warszawa 1991, s. 13-65; P. Iwanicki, Materiały z okresu rzymskiego ze stanowiska I w Woźnej Wsi, gmina Rajgród, województwo podlaskie, [w:] Officina Archaeologica Optima. Studia ofiarowane Jerzemu Okuliczowi-Kozarynowi w siedemdziesiąta rocznice urodzin, red. W. Nowakowski, A. Szela, Warszawa 2001, s. 89).

74 M. Karczewska, Ceramika o powierzchni kreskowanej z międzyrzecza Biebrzy i Narwi, [w:] Ceramika bałtyjska. Tradycje $i$ wpływy. Materiały z konferencji, Białystok, 21-23 września 2005, red. M. Karczewska, M. Karczewski, Białystok 2007 (w druku).

75 T. Maliniwski, Ekspansja kultury pomorskiej i charakter tej ekspansji, [w:] Pradzieje ziem polskich, red. J. Kmieciński, t. I, cz. 2, Warszawa - Łódź, 1989, mapa 27; M. Gedl, Grupy lokalne w obrębie kultury tużyckiej, [w:] Pradzieje ziem polskich, red. J. Kmieciński, t. I, cz. 2, Warszawa - Łódź, 1989, mapa 33, 34; Z. Kobyliński, W. Szymański, Pradziejowe i wczesnośredniowieczne osadnictwo w zespole kemów w Haćkach [w:] J. B. Faliński, A. Ber, Z. Kobyliński, W. Szymański, A. J. Kwiatkowska-Falińska, Haćki. Zespót przyrodniczo-archeologiczny na Równinie Bielskiej, Białowieża - Warszawa, 2005, s. 48.

76 T. Dąbrowska, Wczesne fazy kultury przeworskiej, Warszawa, 1988, s. 64, 67, 73-74, 81, mapa 2.
} 
nad Narwią na wschód od ujścia Biebrzy pod wsią Grądy Woniecko stanowisko 2 (AZP 36-80) ${ }^{77}$. W przypadku stanowisk z Dolistowa Starego, Dolistowa Nowego, Hanulki, Horodnianki, Jaczna, Kolonii Chilmonów Kopytkowa, Krzywej, Kuderowszczyzny, Laudańszczyzny, Małyszówki i Sieburczyna, ich przynależność kulturowa nie została określona. W Karpowiczach natrafiono na ślad osadnictwa kultury ceramiki kreskowanej. Ślad osadnictwa z Burkowa prawdopodobnie związany jest z kulturą łużycką. Natomiast cmentarzysko odkryte pod wsią Grądy Woniecko autorzy badań określili jako przynależne do kultury grobów kloszowych. Odkrycie to wskazuje na konieczność przesunięcia zasięgu występowania grobów kloszowych w kierunku północnym - nad środkową Narew ${ }^{78}$. Rozmieszczenie stanowisk archeologicznych odkrytych w wyniku AZP wskazuje też na istnienie nad górną i środkową Biebrzą, do ujścia Netty i Brzozówki na zachodzie, koncentracji śladów osadnictwa z wczesnej epoki żelaza o przeważnie nieokreślonej przynależności kulturowej (ryc. 7).

Sytuacja kulturowo-osadnicza w okresie wpływów rzymskich i okresie wędrówek ludów, w Kotlinie Biebrzańskiej i na obszarach sąsiednich, ze względu na fragmentaryczność źródeł nie została dotychczas jednoznacznie zdefiniowana. Na północy, na Pojezierzu Ełckim i Równinie Augustowskiej w okresie wpływów rzymskich i wczesnej fazie okresu wędrówek ludów rozwijało się osadnictwo związane z kulturami zachodniobałtyjskiego kręgu kulturowego, obejmującego na ziemiach dzisiejszej Polski północno-wschodniej kultury: bogaczewską i sudowską 79 .

Południową peryferię strefy osadniczej zajętej przez kultury zachodniobałtyjskiego kręgu kulturowego wyznaczają pojedyncze stanowiska odkryte w południowej części Pojezierza Ełckiego i Równiny Augustowskiej oraz w samej Kotlinie Biebrzańskiej. Jedynie niewielka część tych stanowisk badana była wykopaliskowo. Jedna z osad znajdowała się na „Górze Zamkowej” w Rajgrodzie, co

77 Autorami cytowanych badań AZP są: obszar AZP 26-86: W. Stoczkiwski, obszar 26-89: B. Czarnecka i W. Stoczkowski, obszar 28-84: M. Karczewska i M. Karczewski, obszar 28-85: H. Karwowska, obszar 28-86: J. Maciejczuk i K. Rusin, obszar 35-80: M. Zalewski, obszar AZP 36-80: J. Brzozowski i J. Siemaszko. Dokumentacja z badań znajduje się w archiwum Podlaskiego Wojewódzkiego Konserwatora Zabytków w Białymstoku (obszary AZP 26-86, 26-87, 26-89, 27-86, 28-84, 28-85, 28-86) oraz w archiwum Łomżyńskiej Delegatury Służby Ochrony Zabytków (obszary 35-80 i 36-80), teczki nr 200 i 468.

78 T. Węgrzynowicz, Kultura grobów kloszowych, [w:] Prahistoria ziem polskich, t. IV. Od środkowej epoki brązu do środkowego okresu lateńskiego, red. J. Dąbrowski i Z. Rajewski, Wrocław - Warszawa - Kraków, 1979, ryc. 91.

79 M. Kaczyński, Południowa strefa osadnictwa bałtyjskiego na obszarze Jaćwieży w I tysiącleciu naszej ery, „Rocznik Białostocki”, t. XIV, 1981, s. 169-170; W. Nowakowski, Kulturowy krag zachodniobałtyjski $w$ okresie wptywów rzymskich. Kwestia definicji i podziałów wewnętrznych, [w:] Archeologia battyjska. Materiały z konferencji Olsztyn, 24-25 kwietnia 1988 roku, Olsztyn, 1991, s. 42-48, 61, ryc. 1. 
potwierdzają odkryte tam fragmenty glinianych naczyń o cechach ceramiki z podokresu późnorzymskiego i wczesnej fazy okresu wędrówek ludów ${ }^{80}$. Na przełomie okresu wpływów rzymskich i okresu wędrówek ludów osiedle to otoczone zostało bliżej nieokreślonym pasem umocnieñ ${ }^{81}$.

Cmentarzyska z okresu wpływów rzymskich położone na północ od Biebrzy znane są z okolic Rajgrodu: z Bargłowa Dwornego ${ }^{82}$ i Dreństwa ${ }^{83}$, a także z Judzików ${ }^{84}$, Netty ${ }^{85}$, Podliszewa ${ }^{86}$ i Woźnej Wsi8 ${ }^{87}$. Niekiedy, jak w przypadku Bargłowa Dwornego i Netty ${ }^{88}$ towarzyszyły im relikty osad będące, wraz z cmentarzyskiem, reliktem jednego mikroregionu osadniczego.

W tym samym czasie międzyrzecze Biebrzy i Narwi, w świetle źródeł archeologicznych nieuwzględniających jednak wyników badań AZP, jawi się jako obszar niemal bezludny. Sytuacja taka była kontynuacją struktur osadniczych uformowanych jeszcze w ostatnich wiekach przed naszą erą. Osadnictwo kultury przeworskiej sięgało wówczas jedynie nad dolną Narew, by u schyłku wczesnego podokresu wpływów rzymskich objąć również tereny nad środkową i górną Narwią ${ }^{89}$ Również w przypadku kultury wielbarskiej w fazie B2/C1-C1a i w pod-

80 D. Jaskanis, Grodzisko w Rajgrodzie..., s. 112, 115, 116-117, 129.

81 Ibidem, s. 120.

82 J. Marciniak, Dwa cmentarzyska ciałopalne z okresu rzymskiego w Judzikach i Bargłowie Dwornym w pow. augustowskim, „Wiadomości Archeologiczne”, t. XVII, z. 3-4, 1950; M. Kaczyński, Badania stanowisk z okresu rzymskiego na Równinie Augustowskiej, „Rocznik Białostocki”, t. XIII, 1976, s. 475-477; tenże, Ceramika z osady późnorzymskiej (stanowisko II) w Bargtowie Dwornym, gm. Bargłów Kościelny, woj. suwalskie, [w:] Ceramika zachodniobattyjska od wczesnej epoki żelaza do poczatku ery nowożytnej. Materiały z konferencji - Białystok 14-16 maja 1997, red. M. Karczewski, Białystok, 1998, s. 167-168.

83 J. Jaskanis, Grób z okresu rzymskiego - odkryty w Dreństwie pow. Augustów, „Rocznik Białostocki”, t. VIII, 1968, s. 401-404; J. Brzozowski, P. Szymański, Nowe zabytki z cmentarzyska z okresu wpływów rzymskich w miejscowości Dręstwo, stanowisko 1, gm. Bargłów Kościelny, pow. Augustów, ,Światowit”, t. I (LXII) Fascykuł B.

84 J. Marciniak, Dwa cmentarzyska...

85 J. Okulicz, Cmentarzysko z III-V w. naszej ery z miejscowości Netta, pow. Augustów, „Wiadomości Archeologiczne”, t. XXII, z. 3-4, 1955; A. Bitner-Wróblewska, Netta. A Balt Cemetery in Northeastern Poland, Warszawa 2007.

86 A. Bitner-Wróblewska, P. Iwanicki, Cmentarzysko w Podliszewie, woj. podlaskie. Między kultura bogaczewska a sudowska, [w:] Varia Barbarica. Zenoni Woźniak ab amicis dicata, red. J. Andrzejowski, R. Prochowicz, A. Żurawska, Warszawa - Lublin 2002.

87 P. Iwanicki, Materiaty...

88 M. Kaczyński, Badania stanowisk..., s. 479-482; tenże, Ceramika z osady..., s. 168-169. Zobacz też: P. Iwanicki, The Lake Rajgród micro-region - an outlying area of Bogaczewo culture settlement, „Archaeologia Lithuana”, vol. 5, p. 5-15.

89 T. Dąbrowska, T. Liana, Stan i potrzeby badań nad młodszym okresem przedrzymskim i okresem wpływów rzymskich na Mazowszu, [w:] Stan i potrzeby badań nad młodszym okresem przedrzymskim i okresem wpływów rzymskich w Polsce. Materiały z konferencji, Kraków, 14-16 listopada 1984, red. K. Godłowski, R. Madyda-Legutko, Kraków 1986, s. 148, 149, 150, 152, mapa 1. 
okresie późnorzymskim, Narew wyznaczała strefę jej zwartego osadnictwa ${ }^{90}$. Zasiedlanie obszarów położonych bardziej na północy - w międzyrzeczu Narwi i Biebrzy potwierdzają cmentarzyska w Czuprynowie, Jasionowej Dolinie, Teolinie $^{91}$. Pustka osadnicza po obu stronach Biebrzy istniała także przez całą rozwiniętą fazę okresu wędrówek ludów ${ }^{92}$.

Przesłanką wskazującą, że opisana wyżej pustka osadnicza nie musi odzwierciedlać rzeczywistego obrazu zasiedlania Kotliny Biebrzańskiej w pierwszych wiekach naszej ery są dwa domniemane, zniszczone cmentarzyska zlokalizowane na zachodnim skraju środkowego basenu Biebrzy, w pobliżu Goniądza: pod Osowcem i pod Szafrankami. Znajdują się one poza zasięgiem kultur zachodniobałtyjskiego kręgu kulturowego oraz kultury przeworskiej i wielbarskiej. Nieliczny i mało charakterystyczny materiał zabytkowy ze stanowiska pod Osowcem, odkrytego w odległości $1 \mathrm{~km}$ na północ od Biebrzy, nie daje podstaw do sklasyfikowania go pod względem kulturowym. Trudna do określenia jest też przynależność kulturowa szpili (szczypczyków) z Szafranek, wsi na południowym brzegu Biebrzy. Przypomina ona kształtem szpile z obszarów bałtyjskich zaliczone do typu A wg Beckmann - tzw. „Rollenkophnadeln”93. Marian Kaczyński publikując ten zabytek, wskazał analogie z obszaru kultury sudowskiej, nie przesądzając jednak o jego związku z tą kulturą archeologiczną ${ }^{94}$. Związek omawianego zabytku z obszarami bałtyjskimi przyjęła Anna Juga w nowym opracowaniu szpil typu $\mathrm{A}^{95}$. Problem przynależności kulturowej szpili (szczypczyków) z Szafranek nie został też rozstrzygnięty przez Jacka Andrzejowskiego w publikacji poświęconej zespołowi zabytków kultury wielbarskiej z Czuprynowa, gm. Kuźnica Białostocka, omawiającej szeroko problem północno-wschodniej strefy zasięgu tej kultury i sytuacji kulturowej w okresie wpływów rzymskich na obszarach nadnarwiańsko-nadbiebrzańskich ${ }^{96}$.

\footnotetext{
90 Ibidem, s. 155.

91 J. Andrzejowski, Ciekawe materiały z okresu rzymskiego znalezione w Czuprynowie $w$ woj. białostockim, [w:] Nunc de Svebis dicendum est... Studia archaeologica et historica Georgi Kolendo ab amici et discipuli dicata, red. A. Bursche, M. Mielczarek, W. Nowakowski, Warszawa 1995, s. 43 .

92 Porównaj: W. Nowakowski, Zmierzch dawnych czasów czy świt nowej epoki?. Południowa rubież osadnictwa zachodniobałtyjskiego $w$ VI-VII wieku, [w:] Stan i potrzeby badań nad wczesnym średniowieczem $w$ Polsce - 15 lat później, red. W. Chudziak, S. Moździoch, Toruń - Wrocław Warszawa 2006, ryc. 1.

93 B. Beckmann, Die baltischen Metallnadeln der römischen Kaiserzeit, [in:] „Saalburg Jahrbuch”, H. 26, S. 108, Abb. 1: A.

94 M. Kaczyński, Interesujące znalezisko..., s. 356.

95 A. Juga, Rollenkopfnadeln des Typs Beckmann A im westbaltischen Kreis, ,Archaeologia Lithuana", vol. 4, s. 73.

96 J. Andrzejowski, Ciekawe materiały..., s. 35-46, na temat szpili z Szafranek por. s. 43.
} 
Rozpatrując problem określenia przynależności kulturowej zabytku z Szafranek, należy skupić się na pierwotnej funkcji przedmiotu - szczypczykach. Ich formalne podobieństwo do szpil typu A według klasyfikacji B. Beckmann wynika z funkcjonalnego ukształtowania szczypczyków o wąskich cęgach. W czasie przerabiania na szpilę została jedynie zaostrzona górna krawędź najprawdopodobniej ułamanego ramienia szczypczyków. Nie wykonano natomiast dalszych przeróbek upodabniających szpilę (szczypczyki) z Szafranek do egzemplarzy grupy A. Przede wszystkim nie została zrolowana dolna część cęgów. Zabieg ten pozwoliłby na ukształtowanie główki w sposób charakterystyczny dla szpil z grupy A. Również trzon szpili (ramię szczypczyków) pozostał prostokątny w przekroju poprzecznym z charakterystycznym facetowaniem powierzchni zewnętrznej. Nie można więc wykluczyć przypadkowości podobieństwa zabytku z Szafranek do bałtyjskich szpil typu A. Miejsce jego odkrycia na północnej peryferii zasięgu kultury wielbarskiej w stadium B2/C1-C1a oraz w podokresie późnorzymskim ${ }^{97}$ sugeruje związek szpili (szczypczyków) z Szafranek z tą kulturą archeologiczną.

Lukę osadniczą, czytelną w świetle źródeł archeologicznych z okresu wpływów rzymskich, zgromadzonych do początku lat osiemdziesiątych XX w. z obszaru Kotliny Biebrzańskiej, wypełniło, przynajmniej w części, ponad czterdzieści stanowisk archeologicznych odkrytych podczas badań AZP. Stanowiska te, znane są z siedemnastu obszarów AZP położonych na zachód od Lipska w środkowym i dolnym biegu Biebrzy, aż do jej ujścia do Narwi. W przypadku większości z nich autorzy badań nie określili ich przynależności kulturowej ${ }^{98}$. Określenia

97 J. Andrzejowski, Ciekawe materiały..., s. 43.

98 Stanowiska: Horodnianka stanowisko III (AZP 26-86, autor badań: W. Stoczkowski, dokumentacja z badań AZP w archiwum Podlaskiego Wojewódzkiego Konserwatora Zabytków w Białymstoku); Nowa Wieś stanowisko 3 i sadek stanowisko 2 (AZP 26-87, dokumentacja z badań AZP w archiwum Podlaskiego Wojewódzkiego Konserwatora Zabytków w Białymstoku); Kapice - Zaszyjek stanowisko 6 (AZP 28-81, autor badań: W. Jedliński, dokumentacja z badań AZP w archiwum Łomżyńskiej Delegatury Służby Ochrony Zabytków, teczka nr 155); Zabiele stanowisko 39 (AZP 28-84, autorzy badań M. Karczewska, M. Karczewski, dokumentacja z badań AZP w archiwum Podlaskiego Wojewódzkiego Konserwatora Zabytków w Białymstoku); Szafranki stanowiska 1, 3, 4 (AZP 30-82, autor badań: L. Pluta, dokumentacja z badań AZP w archiwum Podlaskiego Wojewódzkiego Konserwatora Zabytków w Białymstoku); Olszowa Droga stanowiska 1 i 3 (AZP 31-81, autorka badań: A. Nowacka, dokumentacja z badań AZP w archiwum Łomżyńskiej Delegatury Służby Ochrony Zabytków, teczka nr 175); Chrzanowo stanowiska 1 i 2, Kolonia Słucz stanowisko 3, Kubra Stara stanowisko 2, Radziłów, stanowisko 3, Racibory stanowisko 6 (AZP 32-79, autor badań: M. Zalewski, dokumentacja z badań AZP w archiwum Łomżyńskiej Delegatury Służby Ochrony Zabytków, teczka nr 179); Okrasin, stanowiska 2, 7 i 8, Ostrowik stanowiska 2 i 4, Racibory stanowiska 1 i 2 (AZP 32-80, autor badań: W. Migal, dokumentacja z badań AZP w archiwum Łomżyńskiej Delegatury Służby Ochrony Zabytków, teczka nr 180); Kąty stanowisko 2, Kubra Przebudówka stanowisko 4, Szyjki stanowisko 1 (AZP 33-79, autor badań: L. Pluta, dokumentacja z badań AZP w archiwum Łomżyńskiej Delegatury Służby Ochrony Zabytków, teczka nr 187); Siestrzanki stanowiska IV i VII (AZP 34-79, autor badań: L. Pluta, do- 
kulturowe umieszczone zostały na Kartach Ewidencji Stanowiska Archeologicznego dla czterech stanowisk z obszaru AZP 36-80, położonego nad Narwią, na wschód od ujścia Biebrzy. Są to stanowiska 9 i 42 w Strękowej Górze, łączone hipotetycznie z kulturą przeworską oraz stanowisko $27 \mathrm{w}$ Grądach Woniecku i stanowisko $24 \mathrm{w}$ Strękowej Górze przypisywane kulturze wielbarskiej99. Z kulturą przeworską związany jest także ślad osadnictwa odkryty na sąsiednim obszarze AZP 36-81 na stanowisku 33 w Strękowej Górze ${ }^{100}$. Nad środkową Biebrzą odnalezione zostały trzy ślady osadnictwa zachodniobałtyjskiego kręgu kulturowego: dwa w Czerwonym Bagnie stanowisko 8 i 16 na obszarze AZP 28-83 ${ }^{101}$ oraz jeden w Zabielach stanowisko 17 na obszarze $28-84^{102}$. Ostatni z punktów osadniczych związanych z zachodniobałtyjskim kręgiem kulturowym znany jest ze stanowiska 1 we wsi Kamień na obszarze AZP 25-86 nad górną Biebrzą ${ }^{103}$. Te bardzo nieliczne jeszcze punkty osadnicze związane $\mathrm{z}$ osadnictwem $\mathrm{z}$ okresu wpływów rzymskich na obszarach nadbiebrzańskich należy uznać za dowód intensywniejszego niż dotąd przypuszczano zasiedlania tych terenów w pierwszych wiekach naszej ery (ryc. 8) ${ }^{104}$.

kumentacja z badań AZP w archiwum Łomżyńskiej Delegatury Służby Ochrony Zabytków, teczka nr 194); Budne stanowisko 1 (AZP 34-80, autorzy badań: W. Migal, M. Zalewski, dokumentacja z badań AZP w archiwum Łomżyńskiej Delegatury Służby Ochrony Zabytków, teczka nr 195); Grądy Małe stanowisko 3 (AZP 35-79, autor badań: R. Soszyk, dokumentacja z badań AZP w archiwum Łomżyńskiej Delegatury Służby Ochrony Zabytków, teczka nr 199); Brzezwy stanowisko 7, Kołodzieje stanowisko 3 (AZP 35-80, autor badań: M. Zalewski, dokumentacja z badań AZP w archiwum Łomżyńskiej Delegatury Służby Ochrony Zabytków, teczka nr 200); Kramkowo stanowisko 10, Ruś stanowisko 4, Sambory stanowisko 4, Wizna stanowisko 6 (AZP 36-79, autorzy badań: J. Brzozowski, J. Siemaszko, dokumentacja z badań AZP w archiwum Łomżyńskiej Delegatury Służby Ochrony Zabytków, teczka nr 490); Grądy Woniecko stanowisko 24, Laskowiec stanowisko 4, Strękowa Góra stanowiska 9, 2, 42 (AZP 36-80, autorzy badań J. Brzozowski, J. Siemaszko, dokumentacja z badań AZP w archiwum Łomżyńskiej Delegatury Służby Ochrony Zabytków, teczka nr 468); Strękowa Góra stanowisko 29 (AZP 36-81, autorzy badań: J. Brzozowski, J. Siemaszko, dokumentacja z badań AZP w archiwum Podlaskiego Wojewódzkiego Konserwatora Zabytków w Białymstoku). W zestawieniu nie zostały uwzględnione wyniki badań AZP na obszarach: $25-85,26-83,26-85,27-84$.

99 Dokumentacja z badań AZP na obszarze 36-80 w archiwum Łomżyńskiej Delegatury Służby Ochrony Zabytków, teczka nr 468, autorzy badań: J. Brzozowski, J. Siemaszko.

100 Dokumentacja z badań AZP na obszarze 36-81 w archiwum Podlaskiego Wojewódzkiego Konserwatora Zabytków w Białymstoku, autorzy badań: J. Brzozowski, J. Siemaszko.

101 Dokumentacja z badań AZP na obszarze 28-83 w archiwum Podlaskiego Wojewódzkiego Konserwatora Zabytków w Białymstoku, autorzy badań: J. Brzozowski, J. Siemaszko.

102 Dokumentacja z badań AZP na obszarze 28-84 w archiwum Podlaskiego Wojewódzkiego Konserwatora Zabytków w Białymstoku, autorzy badań: M. Karczewska, M. Karczewski.

103 Dokumentacja z badań AZP na obszarze 25-86 w archiwum Podlaskiego Wojewódzkiego Konserwatora Zabytków w Białymstoku, autorzy badań: M. Karczewska, M. Karczewski.

104 Szerszego pola do interpretacji nie dają trzy stanowiska archeologiczne odkryte na obszarze AZP 27-82 w miejscowościach: Kuligi st. 6, oraz Kozłówka st. 3 i 5. Ich chronologia i przy- 
W archeologii wczesnego średniowiecza obszarów Pojezierzy Ełckiego i Suwalskiego jednym $\mathrm{z}$ najistotniejszych problemów jest luka w materiałach zabytkowych z okresu od przełomu VI i VII po koniec X wieku, tj. od schyłku okresu wędrówek ludów po ukształtowanie się jaćwieskich terytoriów plemiennych. Taki stan rzeczy wynika przynajmniej po części z bardzo ograniczonego zakresu przeprowadzonych dotychczas badań wykopaliskowych i niepełnego opracowania ich wyników ${ }^{105}$. Powoduje to brak możliwości prześledzenia ewentualnych związków kulturowych i kontynuacji struktur osadniczych ze schyłku starożytności w głąb wczesnego średniowiecza. Co więcej nawet w przypadku dziejów wczesnośredniowiecznej Jaćwieży, mimo rozwoju badań terenowych, niedostatek źródeł archeologicznych sprawia, że w dyskusji nad tą problematyką głos decydujący przypada historykom.

Analiza źródeł historycznych skłoniła Aleksandra Kamińskiego do stwierdzenia, że w XIII wieku północną granicę osadnictwa mazowieckiego i ruskiego wyznaczała Narew, zaś Jaćwież nie przekraczała na południu Biebrzy. Tereny między Biebrzą, Narwią i Świsłoczą miały być puszczą graniczną. Ewentualnych dowodów potwierdzających jej zaludnienie miała dostarczyć archeologia ${ }^{106}$. Biebrzę jako południową granicę wczesnośredniowiecznej Jaćwieży zaakceptowali również archeolodzy ${ }^{107}$.

Południowy zasięg wczesnośredniowiecznej Jaćwieży miało wyznaczać położone na Pojezierzu Ełckim grodzisko w Rajgrodzie. Historycy przypisują Rajgrodowi rolę grodu centralnego jednej z włości jaćwieskich, ważnego ośrodka na szlaku handlowym prowadzącym z ziemi wiskiej (z Mazowsza) do Jaćwieży i grodu granicznego broniącego od południa tego terytorium plemiennego przed atakami z Mazowsza i Rusi ${ }^{108}$. Zły stan zachowania reliktów wczesnośredniowiecznego grodu Raj uniemożliwił szczegółową analizę porównawczą wyników badań archeologicznych z wymową źródeł historycznych i opartymi na nich koncepcjami wysuniętymi przez historyków. Sytuacja Rajgrodu jest zresztą reprezentatywna dla całej problematyki jaćwieskiej rozpatrywanej z perspektywy źródeł archeologicznych. Nie tylko nie dają one podstaw do ustalenia podziałów ple-

należność kulturowa określona została jako „kultura zachodniobałtyjska, okres wędrówek ludów” (Kuligi st. 6) oraz „kultura jaćwieska, okres wędrówek ludów - wczesne średniowiecze” (Kozłówka st. 3 i 5) (Dokumentacja z badań AZP na obszarze 27-82 znajduje się w archiwum Podlaskiego Wojewódzkiego Konserwatora Zabytków w Białymstoku, autorzy badań: J. Brzozowski, J. Siemaszko).

105 D. Jaskanis, Grodzisko w Rajgrodzie..., s. 128.

106 A. Kamiński, Materiały..., s. 194, 198; tenże, Pogranicze..., s. 8-9.

107 J. Antoniewicz, O kilku importach prowincjonalnorzymskich i kultury „wenedzkiej”, znalezionych na obszarach plemiennych Jaćwieży, „Rocznik Białostocki”, t. III, 1962, s. 183-184; D. Jaskanis, Pradzieje Białostocczyzny, Warszawa 1969, s. 61.

108 A. Kamiński, Jaćwież..., s. 98-101; D. Jaskanis, Grodzisko w Rajgrodzie..., s. 75-76. 
miennych, których istnienie wykazały badania historyczne, lecz nawet nie pozwalają na określenie zasięgu przestrzennego Jaćwieży ${ }^{109}$.

Wczesnośredniowiecznym grodem mazowieckim o największym znaczeniu dla pogranicza mazowiecko-rusko-jaćwieskiego, a następnie granicy Mazowsza, Litwy i Państwa Zakonnego w Prusach była Wizna. Ze względu na swe graniczne położenie, gród ten był wielokrotnie oblegani i niszczony przez Prusów, Jaćwingów, Litwinów i Krzyżaków ${ }^{110}$. Szczególna pozycja wśród grodów Mazowsza sprawiła też, że dwunasto- i trzynastowieczne źródła pisane wymieniły Wiznę aż czternaście razy ${ }^{111}$. Dzieje grodu zostały szczegółowo i wszechstronnie opisane w pracy Aleksandra Kamińskiego „Wizna na tle pogranicza polsko-rusko-jaćwieskiego" ${ }^{112}$. Przedstawione w niej i w pracach późniejszych historyków dzieje polityczne oraz ewolucja funkcji Wizny w wielu punktach potwierdzone zostały przez wyniki badań wykopaliskowych. W XI wieku był to gród strzegący dalekosiężnych szlaków komunikacyjnych i handlowych prowadzących z Mazowsza na Ruś oraz ku Jaćwieży i Litwie ${ }^{113}$. Funkcję tę zachowała Wizna również w następnych stuleciach stając się jednocześnie siedzibą kasztelani ${ }^{14}$. Archeologom nie udało się jednak uchwycić materialnych pozostałości wielu faktów znanych z dziejów grodu. Nie zostały odnalezione zabytki potwierdzające ożywione kontakty z ludnością pruską i jaćwieską, czy też odzwierciedlające epizod władztwa ruskiego w Wiźnie ${ }^{115}$. W stratygrafii wału grodziska nie wydzielono śladów przebudowy, jakiej dokonał w 1296 roku książę mazowiecki Bolesław II podnosząc Wiznę z ruin po tym jak w 1294 roku spalili ją Krzyżacy. Wały zostały wówczas podwyższone, a ich zewnętrzną stronę obłożono kamieniami w celu wzmocnienia i zabezpieczenia przed ogniem ${ }^{116}$. Burzliwe, militarne dzieje Wizny znalazły swe potwierdzenie w inwentarzu zabytków odkrytych na grodzisku. Szczególnie charakterystyczne są tu liczne żelazne groty do kuszy odnalezione na jego majdanie ${ }^{117}$.

Od północy gród w Wiźnie zabezpieczał dodatkowo gród w Samborach. Jego funkcja miała polegać na kontrolowaniu ujścia Biebrzy do Narwi. Hipotezę taką wysunął Aleksander Kamiński na podstawie położenia i zbieżności chronologii obu grodów ${ }^{118}$. Miał on być strażnicą kontrolującą obszar ujścia Bie-

\footnotetext{
109 J. Jaskanis, Jaćwież..., s. 64.

110 B. Guerquin, Zamki ..., s. 308; L. Kajzer, St. Kołodziejski, J. Salm, Leksykon zamków, s. 541.

111 A. Kamiński, Wizna..., s. 9.

112 Ibidem.

113 L. Kajzer, St. Kołodziejski, J. Salm, Leksykon zamków..., s. 541.

114 A. Kamiński, Wizna..., s. 17-20, 25, 47, 57-58.

115 Ibidem, s. 22-29.

116 B. Guerqin, Zamki..., s. 308.

117 Wizna, [w:] Informator Archeologiczny. Badania 1967, s. 382.

118 A. i J. Kamińscy, Grodzisko w miejscowośći Sambory..., s. 364; A. Kamiński, Wizna..., s. 40.
} 
brzy do Narwi ${ }^{119}$. Gród w Samborach był przy tym zapewne placówką obserwacyjną, która w momencie zagrożenia miała za zadanie raczej ostrzec załogę grodu w Wiźnie, niż stawić samodzielny, skuteczny opór. Wskazują na to niewielkie rozmiary grodziska, brak rozbudowanego systemu umocnień, którego jedynym elementem był wał, oraz kopica zajmująca większą część majdanu. $\mathrm{Z}$ dużym prawdopodobieństwem można przyjąć, że wyniesienie to było podstawą, najprawdopodobniej drewnianej wieży obserwacyjnej. Ogień rozpalany na jej szczycie mógł być sygnałem dla załogi grodu w Wiźnie. Analogiczny system komunikacji ogniowej był rozbudowany na wschodnim pograniczu Państwa Zakonnego w Prusach, gdzie między zamkami wznosiła się sieć kopców strażniczych zapewniających przesyłanie sygnałów ${ }^{120}$.

Związek administracyjny i militarny musiał też, zdaniem Aleksandra Kamińskiego, istnieć między odległymi o $18 \mathrm{~km}$ w linii prostej grodami w Wiźnie i Pieńkach - Grodzisku. Gród w Pieńkach - Grodzisku, podległy administracyjnie kasztelani wiskiej, miał spełniać podwójną rolę: zabezpieczał północne przedpole Wizny oraz był lokalnym ośrodkiem administrującym zespołem osadniczym położonym wokół grodu ${ }^{121}$.

Poza grodami w Wiźnie i Samborach północnej i północno-wschodniej granicy Mazowsza oraz szlaku handlowego z Mazowsza na Ruś i Litwę miały strzec grody w Goniądzu, pod wsią Grodzisk i w Grodziszczanach ${ }^{122}$. Wczesnośredniowiecznej chronologii wymienionych obiektów nie da się przyjąć bez zastrzeżeń. Po części dlatego, że nie pozostały po nich żadne uchwytne archeologicznie ślady, po części zaś ze względu na bardzo prawdopodobną ich późniejszą metrykę. Grodem, po którym brak wszelkich śladów, jest gród w Goniądzu. Jego istnienie zakładał Aleksander Kamiński ${ }^{123}$. Cytowany autor za grody wczesnośredniowieczne uznał również obiekty we wsiach Grodzisk i Grodziszczany ${ }^{124}$.

Mimo braku systematycznych badań wykopaliskowych istnieją wystarczające podstawy do weryfikacji chronologii i funkcji „grodziska” pod wsią Grodzisk zaproponowanej przez Aleksandra Kamińskiego. Forma reliktów umocnień i drogi prowadzącej do „grodziska”, a także kształt jego majdanu i znajdujące się tam kamienie fundamentowe zdają się wskazywać, że jest to pozostałość dworu na kopcu - późnośredniowiecznej lub nowożytnej rycerskiej siedziby obronnej. Na

\footnotetext{
119 Ibidem, s. 37.

120 Porównaj np. system kopców strażniczych między zamkami w Giżycku i Rynie (kopce: na grodzisku w Jeziorku, w Orle i w okolicy Rynu).

121 Ibidem, s. 41.

122 A. Kamiński, Pogranicze..., s. 10, 11, 15; J. Maroszek, Dzieje Goniądza w 450 rocznice praw miejskich, Białystok - Goniądz 1997, s. 5.

123 A. Kamiński, Pogranicze..., s. 10, 11.

124 Ibidem, s. 14-15; J. Maroszek, Dzieje Goniadza..., s. 3; tenże, Dolina Biebrzy w przeszłości do końca XVIII wieku, „Białostocczyzna”, nr 1 (37), s. 5.
} 
uściślenie chronologii obiektu pozwalają fragmenty ceramiki naczyniowej odkryte na majdanie „grodziska” oraz przylegającej do niego osadzie. Pochodzą one z naczyń XVI-XVII-wiecznych i na ten sam okres należy najprawdopodobniej datować omawiany zespół osadniczy. Pochodzące z tych stanowisk fragmenty naczyń wczesnośredniowiecznych są najprawdopodobniej pozostałością osady otwartej, zasiedlanej co najmniej w dwóch fazach: w IX-X w. i XI-XIII w. Dodatkową przesłanką potwierdzającą hipotezę uznająca „grodzisko" pod wsią Grodzisk za relikt nowożytnego dworu obronnego jest fakt, że jeszcze w okresie międzywojennym ,grodzisko” położone było na granicy pól dworskich i pastwisk włościańskich ${ }^{125}$.

Wbrew wcześniejszym ustaleniom dokonanym przez Romana Jakimowicza i Ludomira Łoźnego, datujących grodzisko w Grodziszczanach na XI-XIII w., również w przypadku tego obiektu można wskazać argumenty ze jego późniejszą - późnośredniowieczną lub nowożytną metryką i uznaniem go za pozostałość dworu na kopcu. Wskazuje na to przede wszystkim forma reliktów umocnień i kształt majdanu, identyczne jak w przypadku „grodziska” pod wsią Grodzisk, różniące się pod tym względem od innych grodzisk o ściśle ustalonej, wczesnośredniowiecznej metryce z obszaru Polski północno-wschodniej. Umocnienia „grodzisk” w Grodziszczanach i pod wsią Grodzisk tworzył pierścieniowaty wał ziemny ze śladami konstrukcji kamiennej na koronie oraz drugi, znacznie niższy wał zewnętrzny, oddzielony od wału wewnętrznego niewielkim obniżeniem o szerokości około $2 \mathrm{~m}$. Oba obiekty nie miały fosy zewnętrznej. Wały zewnętrzne obiektów w Grodziszczanach i pod wsią Grodzisk były wałami odcinkowymi otaczającymi wał wewnętrzny od strony, gdzie nie zabezpieczała go podmokła dolina strugi ${ }^{126}$.

\footnotetext{
125 R. Jakimowicz, Sprawozdanie z ..., s. 214. Kolejnym, domniemanym reliktem ,grodziska” jest „wał” o średnicy 200-300 m odnotowany w 1972 r. pod wsią Czarniewo koło Sztabina. Jego stan zachowania pozwala przypuszczać, że również i w tym przypadku mamy do czynienia z obiektem nowożytnym.

126 Identyczną konstrukcję mają relikty umocnień „grodziska”, a faktycznie dworu na kopcu w Mielewszczyźnie, gm. Korycin, na którym dwór stał jeszcze w czasie II wojny światowej. Gliniany płaszcz z reliktami konstrukcji kamiennej na koronie ma też „grodzisko” w Grodzisku, gm. Grodzisk (nad Bugiem), gdzie dwór stał jeszcze w latach 90-tych XX w. Kolejną cechą wyróżniającą ,grodziska” o metryce późnośredniowiecznej lub nowożytnej od grodzisk wczesnośredniowiecznych jest bardzo mała miąższość warstwy kulturowej zalegającej na majdanie. Potwierdzają to obserwacje majdanów „grodzisk” pod wsią Grodzisk i w Aulakowsczyźnie, gm. Korycin, gdzie w kretowinach widoczny był piasek $\mathrm{z}$ warstwy calca archeologicznego (archiwum własne autora). Uznanie „grodzisk” w miejscowościach Grodzisk i Grodziszczany, a także w Aulakowszczyźnie i Mielewszczyźnie ze relikty dworów na kopcach, dokonane na podstawie cech formalnych i różnic pod tym względem w stosunku do grodzisk o pewnej, wczesnośredniowiecznej chronologii, jest hipotezą badawczą wymagającą weryfikacji w toku badań interdyscyplinarnych, w tym przede wszystkim wykopaliskowych i kwerendy historycznej. Szczególna rola przypada badaniom historycznym, gdyż nikła miąższość warstwy kulturowej stwierdzona na majdanach części „grodzisk” nie napawa optymizmem co do wyników prac wykopaliskowych.
} 
Przy takiej interpretacji chronologii i funkcji ,grodziska” w Grodziszczanach należy wyjaśnić pochodzenie fragmentów wczesnośredniowiecznej ceramiki odkrytej na jego majdanie przez Romana Jakimowicza i Ludomira Łoźnego. Istnieją w tym względzie dwie możliwości. Bardziej prawdopodobna wskazuje, że „grodzisko" powstało w miejscu wczesnośredniowiecznej osady otwartej ${ }^{127}$. Mniej argumentów przemawia za umieszczeniem dworu obronnego na reliktach grodu wczesnośredniowiecznego. Trzeba przy tym pamiętać, że pochodząca z „grodziska” w Grodziszczanach ceramika wczesnośredniowieczna jest przemieszana i nie ma ściśle określonego kontekstu stratygraficznego ${ }^{128}$.

Poza Rajgrodem inne relikty osadnictwa wyznaczające południowy zasięg Jaćwieży nie zostały praktycznie rozpoznane, jeśli nie liczyć trudnych pod względem interpretacji rezultatów badań AZP. Trudność ta wynika przede wszystkim z faktu przyjęcia przez wczesnośredniowieczne garncarstwo bałtyjskie szeregu cech warsztatu ceramicznego charakterystycznego dla kultury materialnej Słowian. W konsekwencji ceramika ta, będąca podstawową kategorią materiału zabytkowego odkrywanego podczas AZP na stanowiskach z epoki żelaza, klasyfikowana jest jako charakterystyczna dla wczesnośredniowiecznej kultury słowiańskiej. Przypisywanie jej bałtyjskej atrybutacji kulturowej na obszarach na północ od Biebrzy wynika z przesłanek historycznych lokujących tam terytorium wczesnośredniowiecznej Jaćwieży. W związku z powyższym wyznaczenie granicy między osadnictwem mazowieckim $\mathrm{i}$ jaćwieskim $w$ strefie nadbiebrzańskiej na podstawie stanowisk odkrytych podczas badań powierzchniowych w ramach AZP nie jest możliwe przy obecnym stopniu poznania ceramiki naczyniowej z tego okresu. Poszukując tej granicy, nadal dysponujemy od strony Jaćwieży jedynie dobrze udokumentowanym w źródłach historycznych i nieco gorzej w archeologicznych grodziskiem w Rajgrodzie. Północny zasięg osadnictwa i wpływów politycznych Mazowsza wyznaczały natomiast grody w Wiźnie, Samborach i Pieńkach - Grodzisku oraz zlokalizowane w ich bliższym i dalszym

\footnotetext{
$127 \mathrm{Z}$ analogiczną sytuacją mamy do czynienia w przypadku reliktów drewnianego zamku Chodkiewiczów w Gródku nad Supraślą (archiwum własne autora). W przypadku Grodziszczan istnienie wczesnośredniowiecznej osady otwartej w bezpośrednim sąsiedztwie obecnego „grodziska” potwierdzone zostało przez odkrycie podczas budowy wodociągu wiejskiego reliktów datowanej na XII-XIII w. półziemianki (Archiwum Wojewódzkiego Urzędu Ochrony Zabytków w Białymstoku, teczka X-1/10/66, Grodziszczany, gm. Dąbrowa Białostocka, relikty grodziska, AZP obszar 27-89, C-46, karta ewidencyjna zabytku).

128 Dodatkowym argumentem za późniejszą nowożytna chronologią „grodziska” w Grodziszczanach przemawiają też wyniki badań AZP na obszarze 27-89. Obok „grodziska” w Grodziszczanach w miejscowości tej zarejestrowano jeszcze tylko jedno stanowisko z ceramiką wczesnośredniowieczną, podczas gdy późniejsze - wczesnohistoryczne osadnictwo w sąsiedztwie „grodziska” potwierdza cały szereg stanowisk na których odkryto fragmenty nowożytnych naczyń ceramicznych teczka AZP 27-89 w archiwum Wojewódzkiego Urzędu Ochrony Zabytków w Białymstoku).
} 
sąsiedztwie cmentarzyska typu mazowieckiego ${ }^{129}$. Inne grodziska wskazywane jako relikty wczesnośredniowiecznych grodów na północno-wschodniej rubieży Mazowsza bądź nie pozostawiły po sobie żadnych uchwytnych archeologicznie śladów (Goniądz), bądź też ich wczesnośredniowieczna metryka budzi zastrzeżenia (Grodzisk).

Ogromny przyrost źródeł do badań nad wczesnym średniowieczem, szczególnie nad jego późną fazą, na obszarach nadbiebrzańskich nastąpił w wyniku realizacji programu AZP. Ich opracowanie przyniesie znaczące przemodelowanie obrazu wczesnośredniowiecznego osadnictwa, uzyskanego na podstawie lokalizacji grodzisk i znajdujących się w okolicy cmentarzysk. Już pobieżna analiza rozmieszczenia stanowisk odkrytych w ramach AZP prowadzi do wypełnienia wielu ,pustek” we wczesnośredniowiecznym krajobrazie osadniczym. Brak tu miejsca na dokładne przedstawienie tej problematyki, która stanowczo przekracza ramy artykułu. Złożoność i wielowątkowość problemu dobrze ilustruje publikacja ozdób odkrytych wraz z dirhemami arabskimi w pochodzącym z X wieku skarbie ze Strękowej Góry ${ }^{130}$. W formie postulatu badawczego wymagającego pilnej realizacji należy natomiast zgłosić ponowne podjęcie wieloaspektowych i interdyscyplinarnych badań nad wczesnym średniowieczem pogranicza bałtyjsko - słowiańskiego nad Biebrzą.

Przytoczone wyżej informacje o prawdopodobnej budowie w czasach Kazimierza Wielkiego zamku w Rajgrodzie wprowadzają nas w problematykę zagospodarowywania ziem wczesnośredniowiecznego pogranicza jaćwiesko-mazowiecko-ruskiego w późnym średniowieczu i czasach nowożytnych. Zagadnienie to wielokrotnie poruszane przez historyków ${ }^{131}$, dotychczas nigdy nie było przedmiotem szczegółowych badań archeologicznych.

\footnotetext{
129 Łączenie typu grobu z osadnictwem mazowieckim może budzić słuszne zastrzeżenia wynikające ze złożonego charakteru rozprzestrzeniania się rytuałów pogrzebowych. Pewnym argumentem za słusznością takiego postępowania, w tym konkretnym przypadku, jest odrębność religii zchrystianiowanego Mazowsza i pogańskiej Jaćwieży. Przykładem dobrze ilustrującym konsekwentny nakaz ciałopalenia w religii Prusów i Jaćwingów są wyniki badań na cmentarzysku przygrodowym w Święcku Strumianach - dawnej kasztelani święckiej. W pobliżu reliktów kościoła na tym cmentarzysku, wśród pochówków szkieletowych odzwierciedlających wprowadzony przez chrześcijaństwo nakaż inhumacji, odkryto pojedynczy grób ciałopalny popielnicowy. Zdaniem Autorki badań prawdopodobnym jest, że był to pochówek dwóch przedstawicieli ludności bałtyjskiej, którzy zmarli w czasie pobytu w Święcku (D. Jaskanis, Układ przestrzenny cmentarzyska we wczesnośredniowiecznym zespole osadniczym $w$ Święcku Strumianach na wschodnim Mazowszu, [w:] Kraje stowiańskie w wiekach średnich. Profanum i sacrum, Poznań 1998, s. 542-543).

130 S. Małachowska, Srebrne ozdoby z wczesnośredniowiecznego skarbu z Góry Strękowej, gm. Zawady, woj. łomżyńskie, „Wiadomości Archeologiczne”, t. LIII, z. 1, 1993-1994, s. 39-44.

131 J. Wiśniewski, Dzieje osadnictwa w powiecie augustowskim od XV do końca XVIII wieku, [w:] Studia i materiaty do dziejów Pojezierza Augustowskiego, red. J. Antoniewicz, Białystok, s. 19-89; tenże, Dzieje osadnictwa w powiecie grajewskim...
} 
Również na wczesnośredniowiecznym grodzisku w Wiźnie odkryte zostały relikty zabudowy pochodzące z czasów późniejszych - średniowiecza i okresu nowożytnego. Pierwsze murowane budowle w obrębie obwałowań powstały zapewne już w początku XV wieku, w czasie gdy Wizna była własnością księcia warszawskiego i ciechanowskiego - Janusza I Starszego. W 1409 roku wzniósł on tu dwukondygnacyjną, murowaną wieżę bramną. Architektura murowana grodu wizneńskiego przetrwała aż do drugiej połowy XIX wieku ${ }^{132}$. Z wcześniejszych odkryć i przekazów wiadomo, że mur okalający cmentarz w Wiźnie został zbudowany z kamieni wykopywanych na majdanie grodziska. Również Roman Jakimowicz $\mathrm{w}$ rowie przecinającym środek majdanu - okopie $\mathrm{z}$ czasów I wojny światowej - odnotował „duże ilości kamieni pochodzących zapewne $\mathrm{z}$ fundamentów drewnianego zamku". Z powierzchni grodziska zebrał natomiast liczne fragmenty ceramiki średniowiecznej ${ }^{133}$. Niestety, jedyne opracowanie badań wykopaliskowych przeprowadzonych tu w latach 1967-1970 pomija zupełnie tę problematykę ${ }^{134}$. Jest to brak tym większy, że - jak zaznaczono wcześniej - to właśnie Wizna już od wczesnego średniowiecza była kluczowym ośrodkiem organizującym osadnictwo mazowieckie na interesującym nas obszarze.

Podobnie jak w przypadku wczesnego średniowiecza, również dla późnego średniowiecza i czasów nowożytnych realizacja badań AZP przyniosła niespotykany wcześniej przyrost liczby źródeł archeologicznych. Nierównomierny stopień rozpoznania archeologicznego tą metodą obszarów nadbiebrzańskich, przy jednoczesnej ogromnej masie źródeł już okrytych, czyni, jak dotąd, bezzasadnym podejmowanie całościowej analizy archeologiczno-osadniczej dla tych okresów. Analiza taka musiałaby przy tym uwzględnić istniejące źródła i opracowania historyczne dotyczące tego tematu, co w praktyce prowadzi do konieczności podejmowania w tym zakresie interdyscyplinarnych prac zespołowych.

Dobrym przykładem możliwości wykorzystania metody archeologicznej w rozstrzyganiu zagadnień szczegółowych dotyczących średniowiecznego i nowożytnego osadnictwa jest problem lokalizacji osady Targowisko i krzyżackiego zamku Metenburg. W badaniach historycznych prowadzonych w latach dziewięćdziesiątych XX wieku nad obszarem Kotliny Biebrzańskiej, problemowi temu poświęcono szczególnie dużo uwagi. Osadę Targowisko wymienia pierwszy dokument odnoszący się do terenów międzyrzecza Biebrzy i Narwi - akt księcia Kiejstuta z 1358 roku zawierający opis przebiegu granicy między Litwą i północno - wschodnim Mazowszem ${ }^{135}$. Targowisko (w oryginale Thargouisko)

132 B. Guerqin, Zamki..., s. 308; L. Kajzer, St. Kołodziejski, J. Salm, Leksykon zamków..., s. 541.

133 R. Jakimowicz, Sprawozdanie z ..., s. 206.

134 I. Jastrzębska, Grodzisko w Wiźnie...

135 A. Kamiński, Pogranicze..., s. 7. 
położone było nad Biebrzą, w miejscu, gdzie granica między włościami Kiejstuta i Siemowita Mazowieckiego skręcała znad Biebrzy ku południowi wzdłuż „Vsczewelikey strugi” zwanej obecnie Brzozówką ${ }^{136}$. Badania historyczne lokalizują owo Targowisko w miejscu dzisiejszego Dolistowa ${ }^{137}$.

W 1382 roku książęta mazowieccy zastawili ziemię wiską aż po rzekę Brzozówkę Krzyżakom, którzy w 1392 roku wznieśli na zajętych terenach dwa zamki. Pierwszy z nich - zamek Neugarden zbudowany został nad Niemnem, naprzeciwko Grodna. Drugi - zamek Metenburg - na bliżej nieokreślonym obszarze nad rzeką Nettą. Jeszcze w tym samym roku oba zamki zostały zniszczone przez księcia Witolda ${ }^{138}$. Wbrew wcześniejszej propozycji Jerzego Wiśniewskiego, który doszukiwał się miejsca po zamku Metenburg w Augustowie, w myśl nowej hipotezy należałoby lokalizować wymieniony zamek na gruntach dzisiejszej wsi Dolistowo Stare. Argumentem za taką lokalizacją zamku miało być położenie Dolistowa na wprost dawnego ujścia rzeki Netty do Biebrzy oraz istnienie tu kościoła już około 1500 roku - w czasach poprzedzających podjęcie akcji kolonizacyjnej Puszczy nad Biebrzą. Wezwanie kościoła - Św. Stanisława Biskupa stworzyło przesłankę do przesunięcia jego początków aż po około „1358 r., gdy „Targowisko funkcjonowało przy kościele katolickim pod takim wezwaniem”139. Dodatkowym argumentem przemawiającym za lokalizacją Metenburga na gruntach późniejszego Dolistowa Starego miała być nazwa jednej z łąk nadbiebrzańskich - „Grodzisk”"140.

Łąkę zwaną „Grodzisk” („Grodzisko”), położoną nad Biebrzą, na wysokości Dolistowa Starego, po raz pierwszy wizytował w 1922 roku Roman Jakimowicz. W publikacji wyników badań podał: ,żadnych śladów grodziska na niej nie dostrzegłem”"141. Ponownie łąka „Grodzisk” stała się obiektem badań archeologicznych wiosną 1998 roku $^{142}$. Weryfikacja stanowiska dała wynik negatywny. $\mathrm{Na}$ jego powierzchni, podobnie jak w 1922 roku, nie zaobserwowano śladów grodziska, a w kretowinach nie natrafiono na materiał zabytkowy. Topografia terenu stanowiska oraz informacje zebrane wśród mieszkańców Dolistowa Starego

\footnotetext{
136 Ibidem.

137 J. Maroszek, Dolina Biebrzy..., s. 4; tenże, Dzieje Goniadza..., s. 5-6; tenże, Pogranicze Litwy i Korony w planach króla Zygmunta Augusta, Białystok 2000, s. 43.

138 J. Maroszek, Dolina Biebrzy..., s. 4.

139 Ibidem, s. 5; tenże, Dzieje Goniądza..., s. 7; tenże, Pogranicze Litwy i Korony..., s. 48.

140 Informację o miejscu zwanym „Grodzisk” otoczonym starym i nowym korytem Biebrzy przekazał w 1996 r. do redakcji „Białostocczyzny” Marek Wojtkiewicz stawiając hipotezę, że jest to miejsce po zamku Metenburg (M. Wojtkiewicz, Ślady krzyżackiego zamku Metenburg w Dolistowie?, „Białostocczyzna”, nr 2 (42), s. 114.

141 R. Jakimowicz, Sprawozdanie z ..., s. 214.

142 Badania powierzchniowe metodą AZP na obszarze 28-84 prowadził autor wraz z M. Karczewską w dniach 26-28 kwietnia 1998 roku.
} 
i Nowego o pochodzeniu nazwy „Grodzisk” przemawiają przeciwko lokalizacji w tym miejscu jakichkolwiek umocnień. Obszar zajmowany przez łąkę jest płaski, z licznymi zagłębieniami, nie wyniesiony ponad dno doliny Biebrzy i okresowo przez nią zalewany. Nazwa łąki, zdaniem mieszkańców Dolistowa pochodzi od odgrodzenia łąki przez nowe koryto Biebrzy, które powstało podczas regulacji rzeki przy budowie Kanału Augustowskiego.

W świetle wyników badań AZP problematyczne wydaje się także jednoznaczne łączenie osady Targowisko z dzisiejszym Dolistowem. Co prawda we wsi i w jej najbliższej okolicy odnalezione zostały ślady osadnictwa wczesnoi późnośredniowiecznego, ale nie było to jedyne miejsce nad Biebrzą, w pobliżu ujścia Brzozówki, gdzie takie ślady odkryto. Znacznie bardziej intensywne ślady zasiedlania pochodzące $\mathrm{z}$ wczesnego i późnego średniowiecza, w formie trzydziestu jeden punktów osadniczych, określanych w nomenklaturze archeologicznej mianem „osad” i „śladów osadnictwa”, oraz jednego cmentarzyska, rozpoznane zostały w sąsiedniej wsi Zabiele. Co więcej, wieś ta, położona bliżej ujścia Brzozówki do Biebrzy, ściślej odpowiada lokalizacji Targowiska wymienionego w traktacie granicznym z 1358 roku.

Przedstawiony wyżej zarys problematyki epoki żelaza obszarów nadbiebrzańskich jest pierwszą próbą ujęcia tematu, przez to daleką od jego wyczerpania. Liczne, zawarte w nim znaki zapytania i niedopowiedzenia odzwierciedlają $\mathrm{z}$ jednej strony niewystarczający stan rozpoznania archeologicznego obszaru, z drugiej zaś dotychczasowy brak zainteresowania archeologów szeregiem zagadnień szczegółowych. Dotyczy to zarówno niejasnej pozycji strefy nadbiebrzańskiej w podziałach kulturowych poszczególnych odcinków pradziejów w obrębie epoki żelaza, jak też jej roli we wcześniejszych odcinkach wczesnego średniowiecza. Lepiej wyglądają na tym tle czasy X-XIII wieku. Dzieje się tak zarówno za sprawą badań prowadzonych przez historyków, jak też samych archeologów uwzględniających w swych pracach, obok źródeł archeologicznych, w coraz większym zakresie również źródła historyczne. Zupełnie dotychczas niewykorzystaną szansą są możliwości interdyscyplinarnych badań prowadzonych wspólnie przez archeologów i historyków nad dziejami osadnictwa tego obszaru w średniowieczu i czasach nowożytnych. W dotychczasowej dyskusji nad zasiedlaniem „,puszcz pojaćwieskich", zainicjowanej jeszcze w ramach Kompleksowej Ekspedycji Jaćwieskiej, a toczącej się na gruncie historii i językoznawstwa argumenty zdają się być już wyczerpane ${ }^{143}$. Czas najwyższy, aby archeolodzy podjęli tę problema-

143 Porównaj np. dyskusję między Jerzym Wiśniewskim i Knutem Olofem Falkiem (J. Wiśniewski, Domniemane ślady osad jaćwieskich w puszczach pojaćwieskich, „Rocznik Białostocki”, t. I, 1961, s. 223-231; tenże, Kilka uwag o osadnictwie południowych puszcz pojaćwieskich od XV do XVII w., „Rocznik Białostocki”, t. I, 1961, s. 305-309; O. Falk, Kilka uwag w sprawie osadnictwa południowych puszcz, pojaćwieskich od XV do XVII w., „Rocznik Białostocki”, t. I, s. 311-316). 
tykę badawczą, spełniając tym samym postulat zgłaszany wielokrotnie pod ich adresem ${ }^{144}$.

\section{The History of Settlement of the Biebrza Valley in the Iron Age}

During over 150 years of archeological researches in the Biebrza Valley only few sites dated from the Early Iron Age until early historical times were discovered. They were forthills in: Grodzisko, Grodziszczany, Pieńki-Grodzisko, Rajgród, Sambory and Wizna. Cemeteries from early and late medieval times and from the early historical times were discovered in: Jacewko, Jedwabne, Jatwież Mała, Kąty, Kokoszki, Kotowo, Okopy, Pieńki-Grodzisko, Rostki Małe, Ruś, Suchowola, Wilamówka and Zabiele.

Relicts of settlements as well as sites dated from the Early Iron Age, Roman Period and Great Migration period had been undiscovered until the eighties of XX century, when the Polish Archeological Record began.

The sites mentioned above are the source base for reconstruction of settlement and cultural differentiation of the Biebrza Valley in the Early Iron Age, Roman Period and Great Migration Period, medieval and early historical times. The main problem of the Early Iron Age until the beginning of early medieval times is the problem of borderlines between Baltic tribes (Culture of the Westbaltic Barrows, Hatched Pottery Culture, Sudowska Culture and the Prudziszki Phase) and German tribes (Przeworsk Culture and Wielbark Culture). According to the early medieval times, it is also the problem of Baltic-Slaves borderland and the cultural interaction. The medieval and early historical times were periods when the Post-Jatvingan primeval forests (germ. Wildnis) were settled. In this context, very important questions are those referring to the origin of new settlers, the range of settled zone and the possibility of survival of some groups of Jatvingan people. Studies on all those problems require verification and new interpretations of several archeological sources.

\footnotetext{
144 A. Kamiński, Jaćwież..., s. 37, 45 tenże,, Wizna.., s. 34, J. Wiśniewski, Domniemane ślady osad jaćwieskich..., s. 230; J. Maroszek, Dzieje Goniądza..., s. 7.
} 


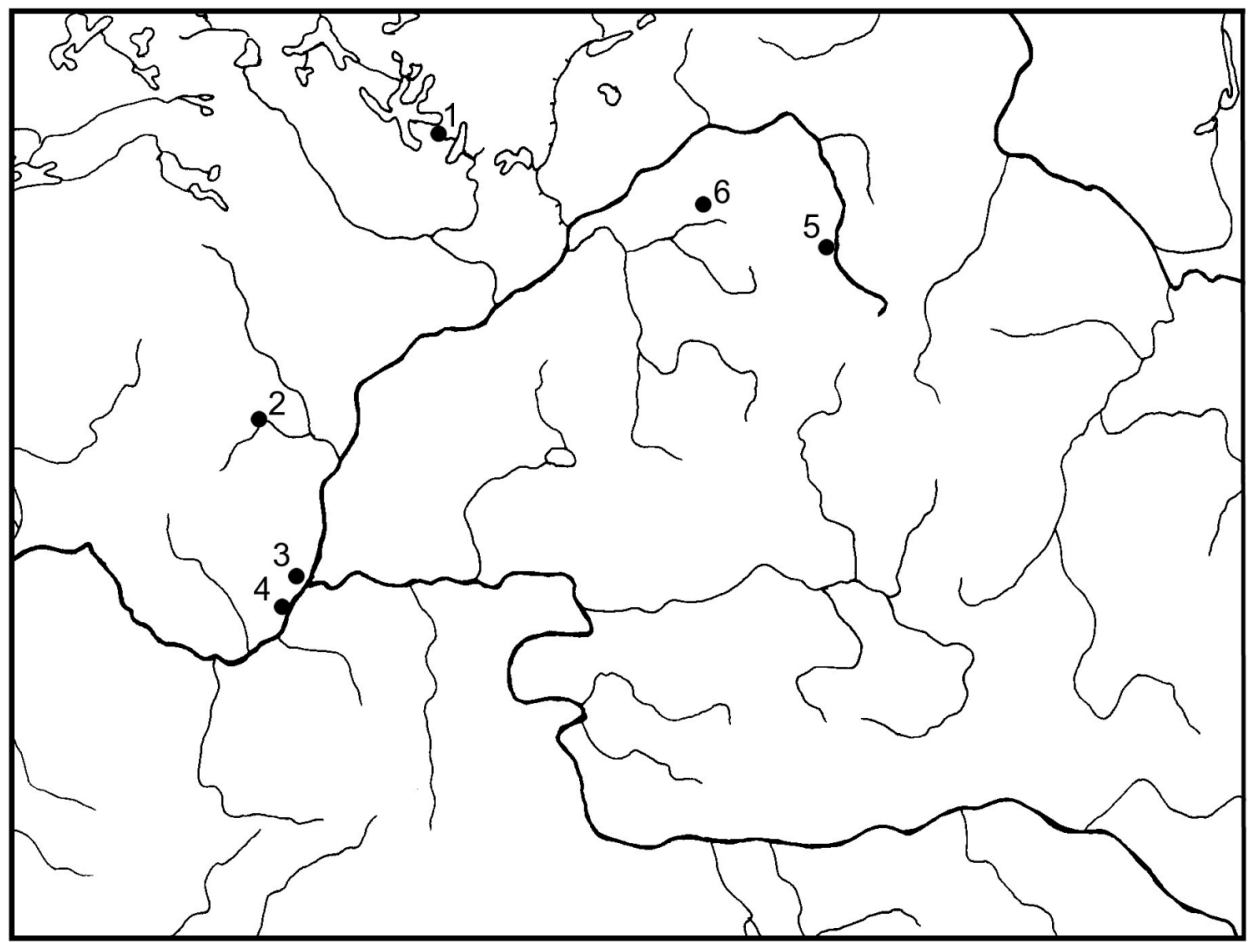

Ryc. 1. Nadbiebrzańskie grodziska: 1 - Rajgród, 2 - Pieńki-Grodzisko, 3 - Sambory, 4 - Wizna, 5 - Grodziszczany, 6 - Grodzisk; oprac. M. Karczewski

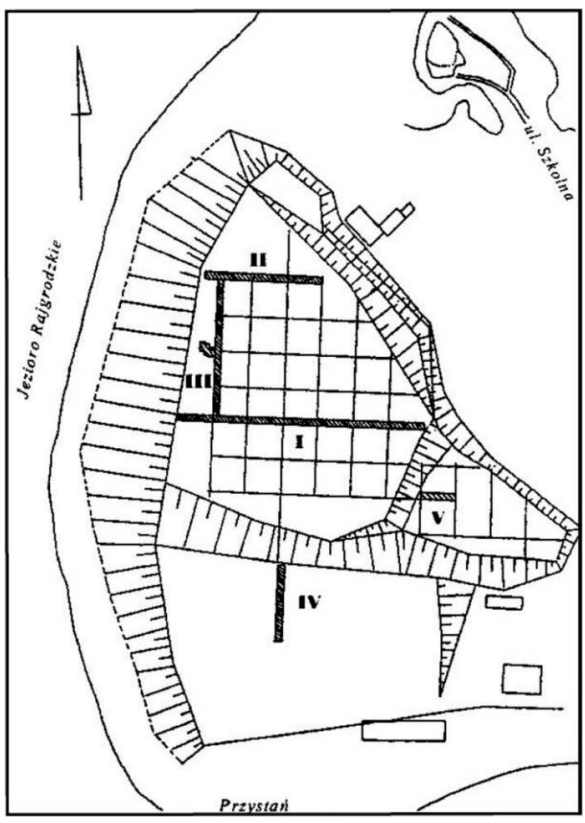

Ryc. 2. Grodzisko w Rajgrodzie. Lokalizacja wykopów badawczych I-V z 1969 r.; wg D. Jaskanis 2001, ryc. 4 
Ryc. 3. Grodzisko w Rajgrodzie. Zabytki odkryte w 1969 r. w wykopie I; wg. D. Jaskanis 2001

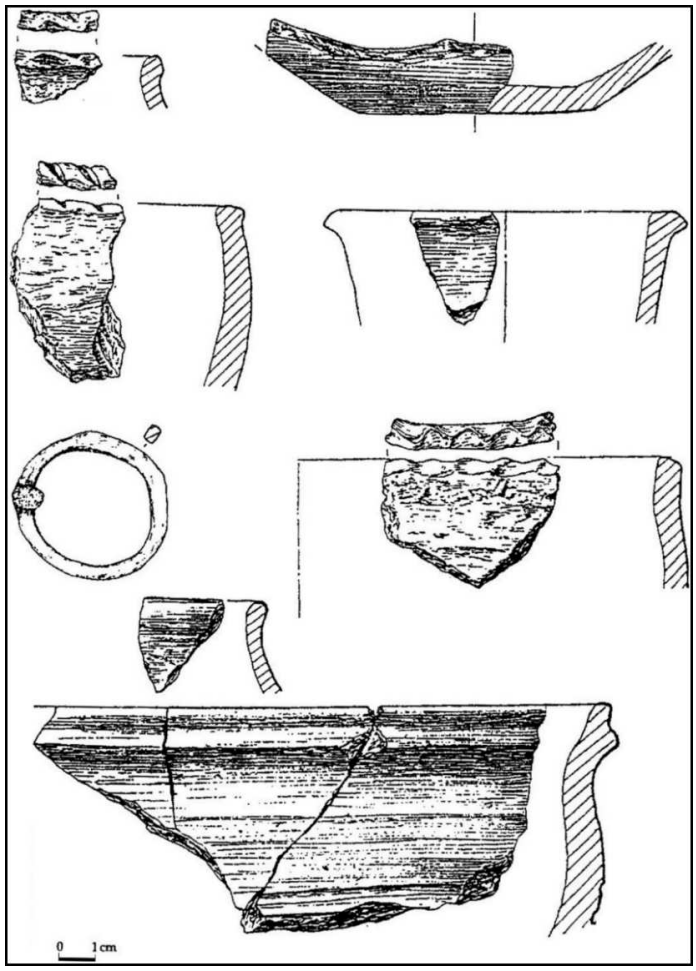

Ryc. 4. Grodzisk. Zabytki odkryte na powierzchni stanowisk: 1-3 (grodzisko stanowisko 1), 4-8 (osada podgrodowa stanowisko 2); oprac. M. Karczewski

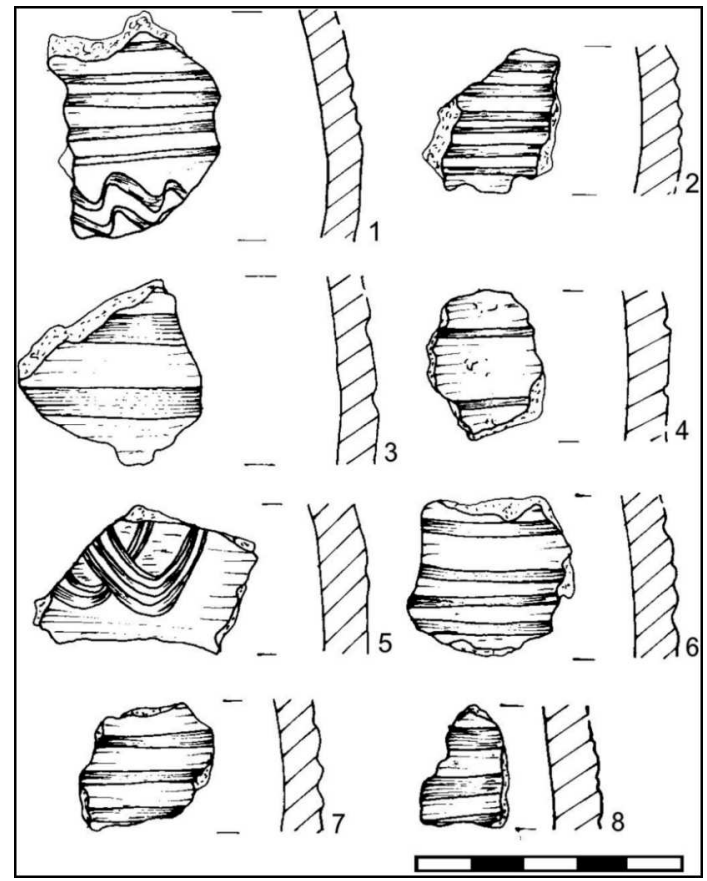




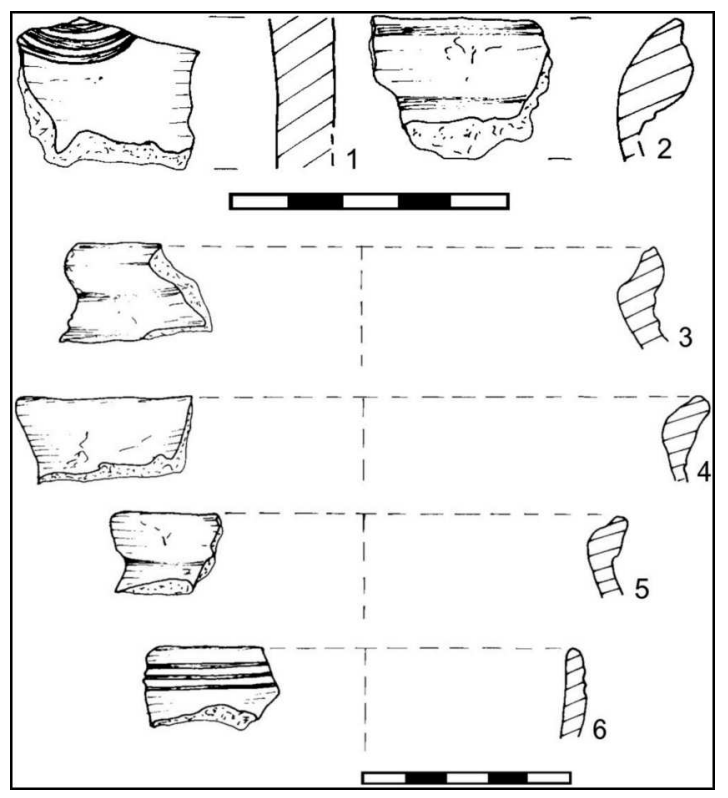

Ryc. 5. Grodzisk. Zabytki odkryte na powierzchni osady podgrodowej (stanowisko 2); oprac. M. Karczewski

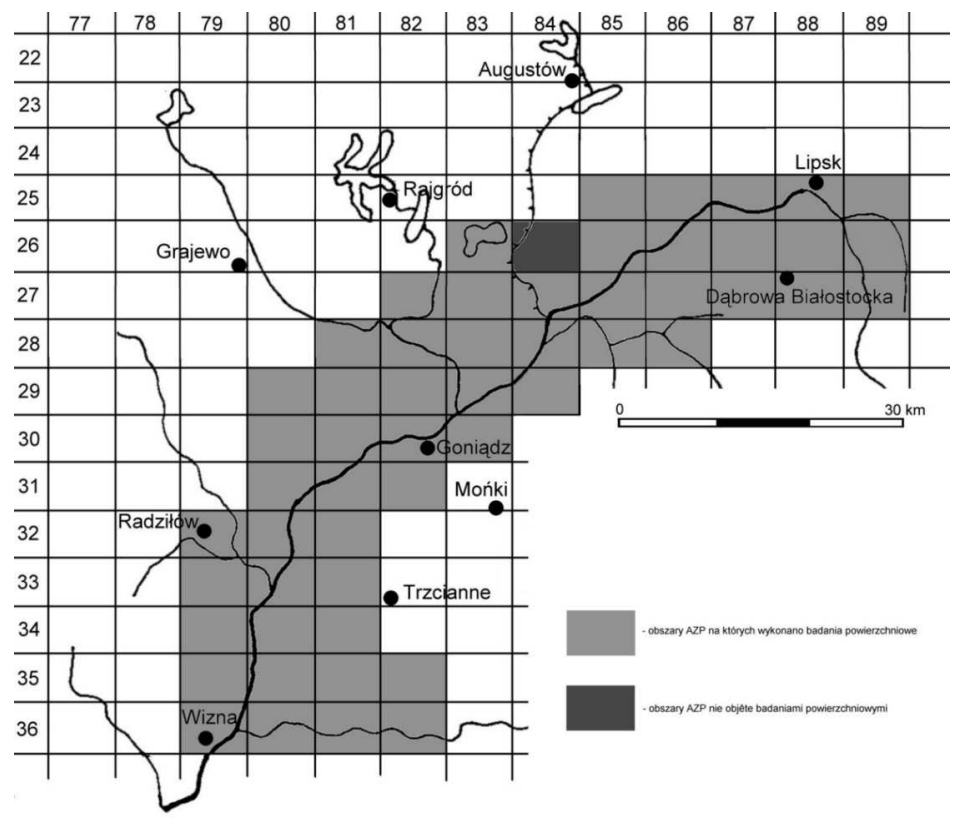

Ryc. 6. Stan rozpoznania archeologicznego Kotliny Biebrzańskiej w ramach Archeologicznego Zdjęcia Polski; oprac. M. Karczewski 


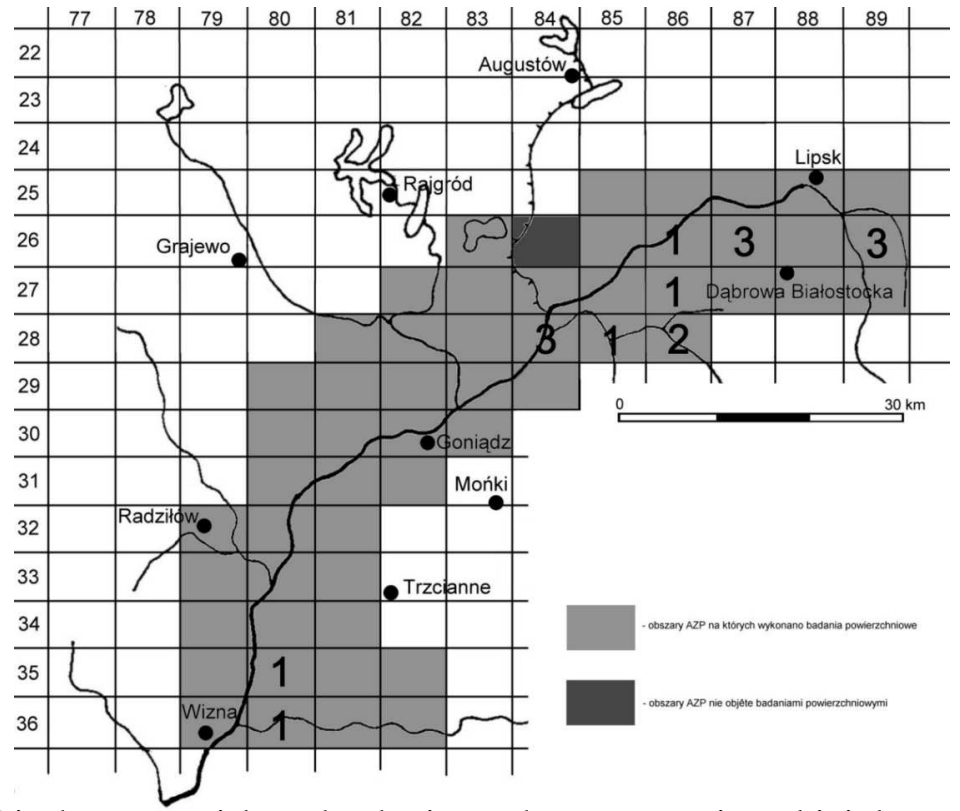

Ryc. 7. Liczba stanowisk archeologicznych z wczesnej epoki żelaza odkrytych podczas badań Archeologicznego Zdjęcia Polski w Kotlinie Biebrzańskiej i na obszarach sąsiednich; oprac. M. Karczewski

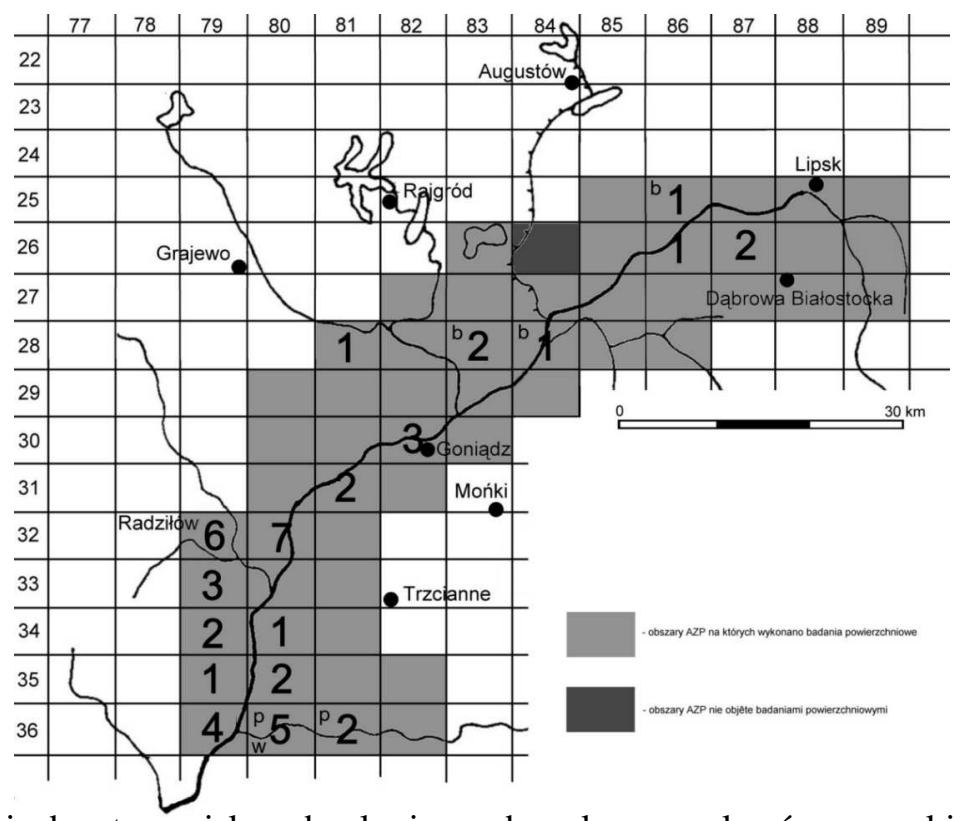

Ryc. 8. Liczba stanowisk archeologicznych z okresu wpływów rzymskich odkrytych podczas badań Archeologicznego Zdjęcia Polski w Kotlinie Biebrzańskiej i na obszarach sąsiednich; oprac. M. Karczewski 


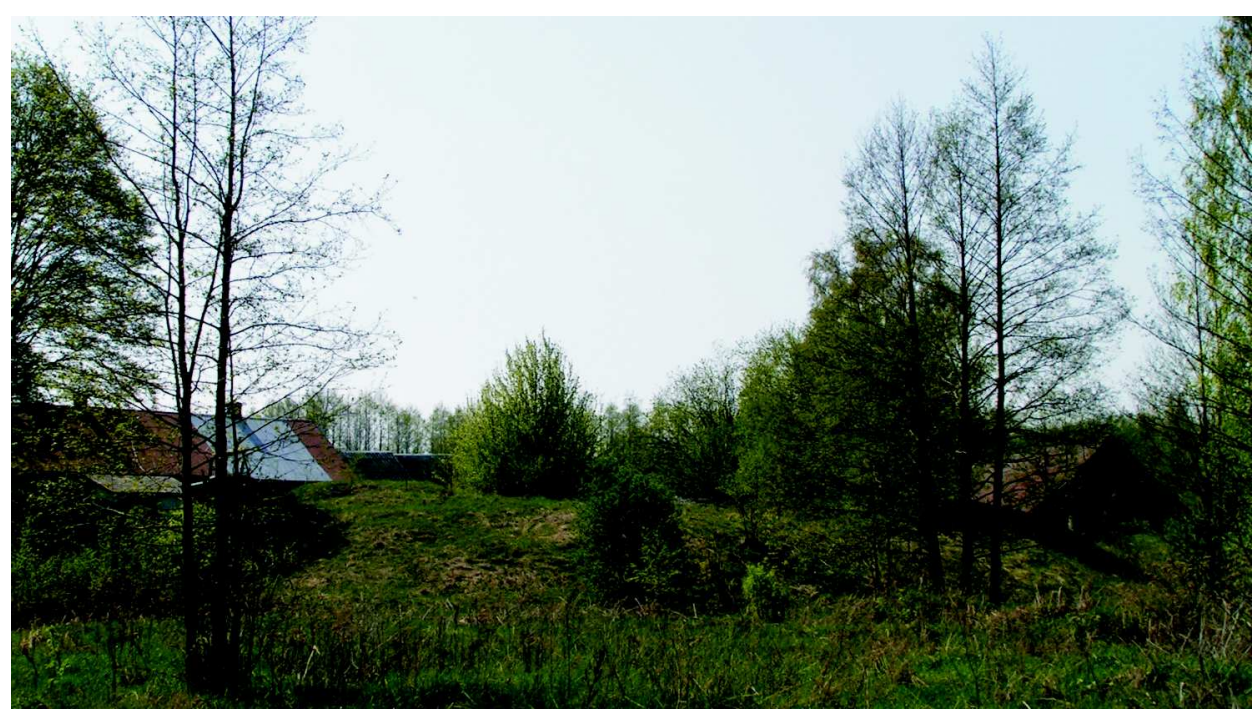

Fot. 1. Grodzisko w Grodziszczanach, gm. Dąbrowa Białostocka; zdj. M. Karczewski

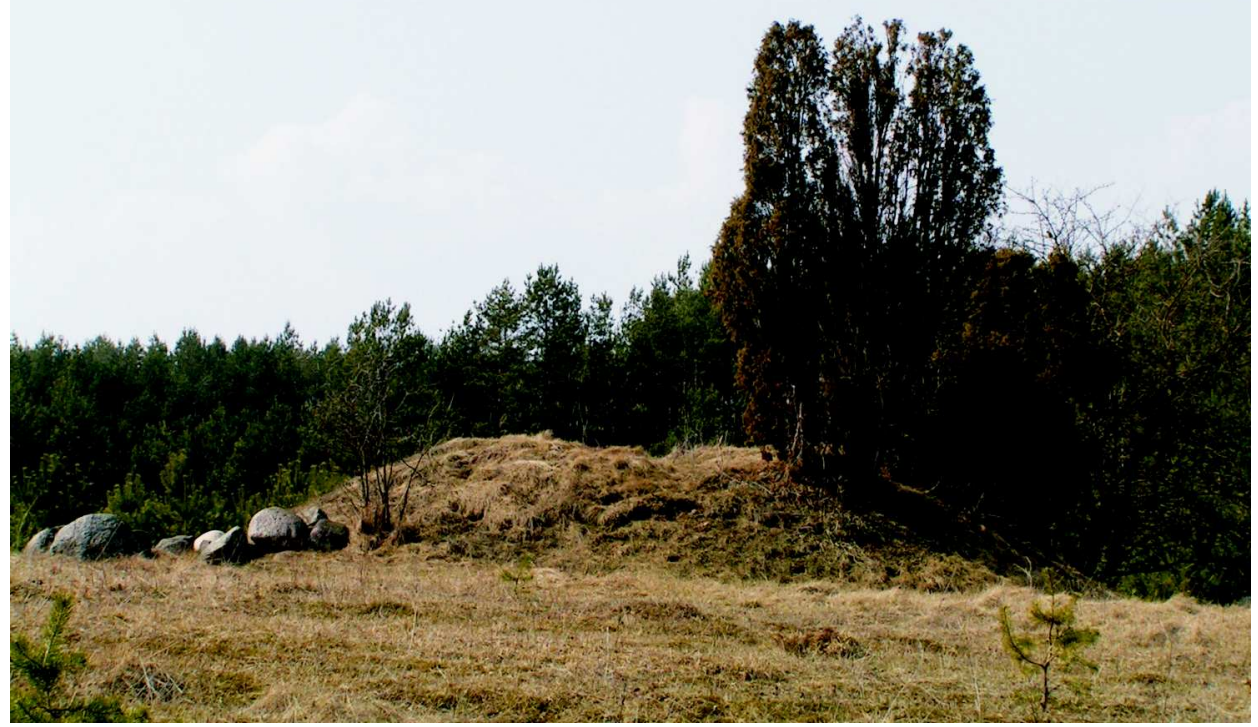

Fot. 2. Kurhan pod wsią Okopy, gm. Suchowola; zdj. M. Karczewski 


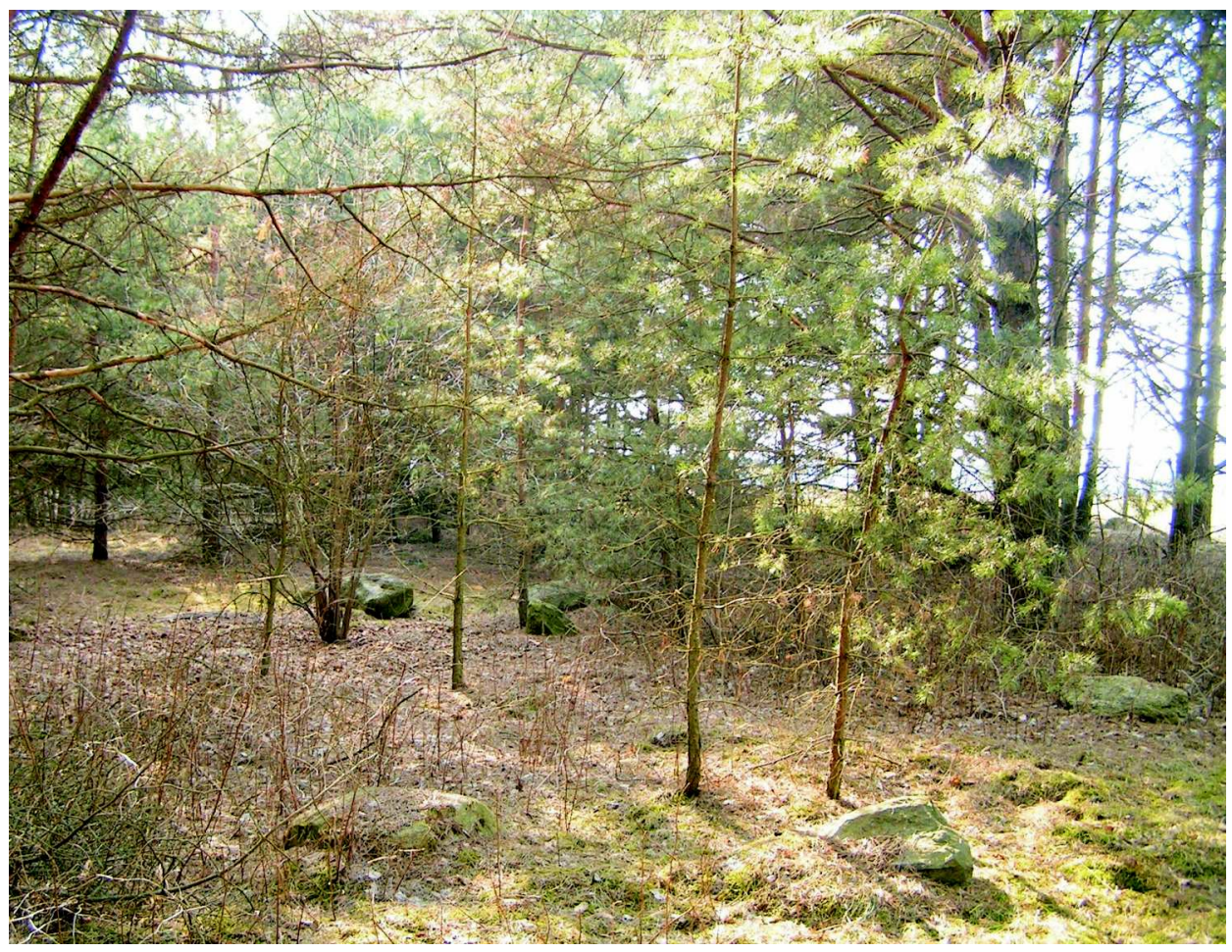

Fot. 3. Cmentarzysko ze stelami kamiennymi w Jatwieży Małej; zdj. M. Karczewski 